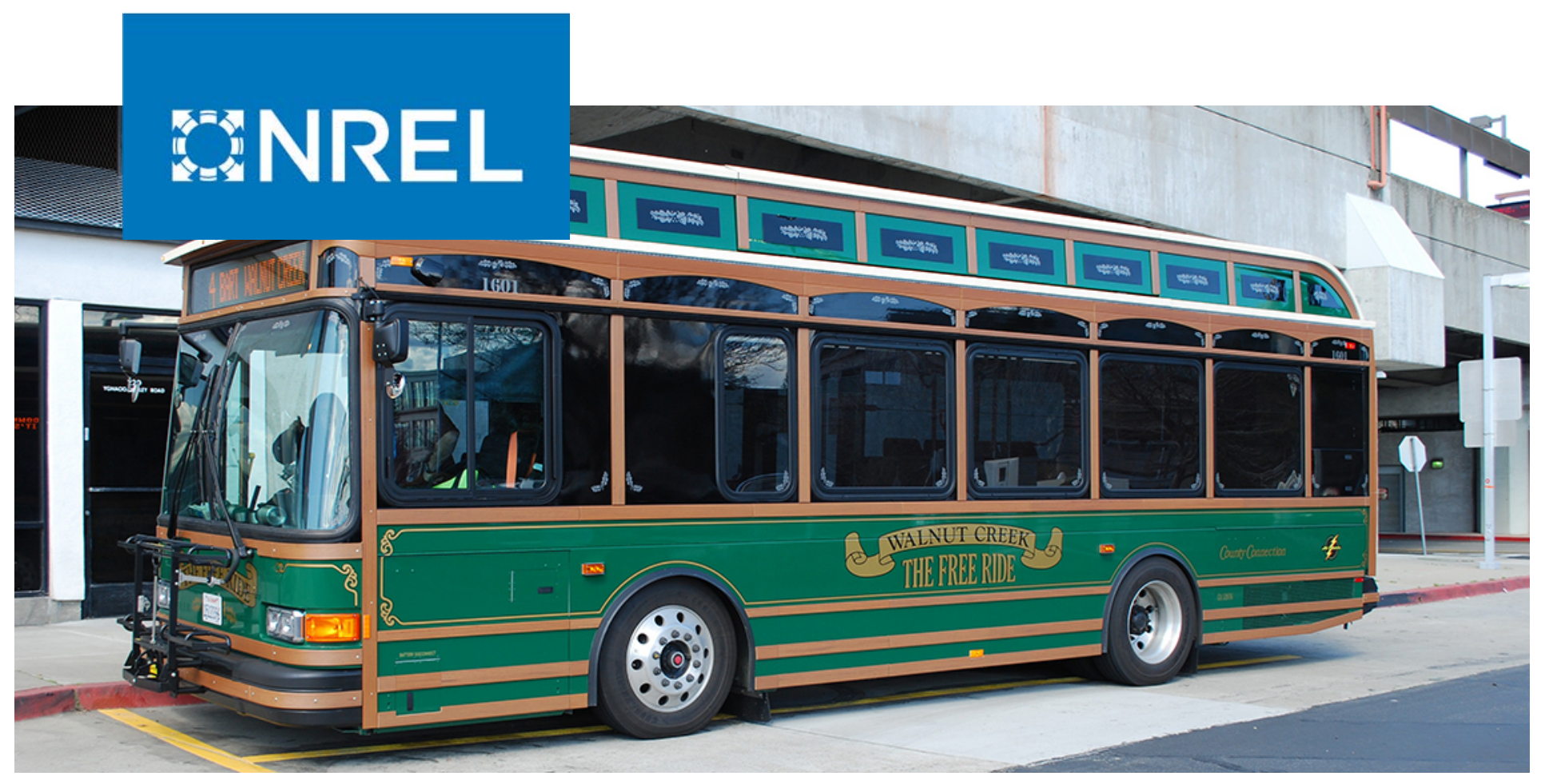

\title{
Zero-Emission Bus Evaluation Results: County Connection Battery Electric Buses
}

Leslie Eudy and Matthew Jeffers

National Renewable Energy Laboratory

Produced under direction of the U.S. Department of Transportation by the National Renewable Energy Laboratory (NREL) under Interagency Agreement IAG-16-2025.

NREL is a national laboratory of the U.S. Department of Energy Office of Energy Efficiency \& Renewable Energy

Operated by the Alliance for Sustainable Energy, LLC

This report is available at no cost from the National Renewable Energy Laboratory (NREL) at www.nrel.gov/publications.
Strategic Partnership Project Report NREL/TP-5400-72864

December 2018 


\title{
FANEL
}

\section{Zero-Emission Bus Evaluation Results: County Connection Battery Electric Buses}

\author{
Leslie Eudy and Matthew Jeffers
}

National Renewable Energy Laboratory

\section{Suggested Citation}

Eudy, Leslie and Matthew Jeffers. 2018. Zero-Emission Bus Evaluation Results: County Connection Battery Electric Buses. Golden, CO: National Renewable Energy Laboratory. NREL/TP-5400-72864. https://www.nrel.gov/docs/fy19osti/72864.pdf.

NREL is a national laboratory of the U.S. Department of Energy Office of Energy Efficiency \& Renewable Energy Operated by the Alliance for Sustainable Energy, LLC

This report is available at no cost from the National Renewable Energy Laboratory (NREL) at www.nrel.gov/publications.

Contract No. DE-AC36-08GO28308
Strategic Partnership Project Report NREL/TP-5400-72864

December 2018

National Renewable Energy Laboratory 15013 Denver West Parkway Golden, CO 80401

303-275-3000 • www.nrel.gov 


\section{NOTICE}

This work was authored by the National Renewable Energy Laboratory, operated by Alliance for Sustainable Energy, LLC, for the U.S. Department of Energy (DOE) under Contract No. DE-AC36-08G028308, and U.S. Department of Transportation under Agreement IAG-16-2025. Funding provided by Department of Transportation, Office of Research, Demonstration and Innovation. The views expressed herein do not necessarily represent the views of the DOE or the U.S. Government.

This report is available at no cost from the National Renewable Energy Laboratory (NREL) at www.nrel.gov/publications.

U.S. Department of Energy (DOE) reports produced after 1991 and a growing number of pre-1991 documents are available free via www. OSTI.gov.

Cover Photo by Leslie Eudy: NREL 54529.

NREL prints on paper that contains recycled content. 


\section{Acknowledgments}

This report could not have been possible without the cooperation of the transit agencies, manufacturer partners, and others. Transit agency staff provided data on the zero-emission and baseline buses; reviewed analyses and reports; and participated in meetings to discuss the agency's overall experience. Manufacturers provided selected data, reviewed reports, and provided feedback. The U.S. Department of Transportation's Research, Development, and Technology Office provided funding for the evaluation. The authors thank the following individuals:

U.S. Department of Transportation Research, Development, and Technology Office Shawn Johnson

U.S. Department of Transportation Federal Transit Administration, Office of Research, Demonstration and Innovation

Sean Ricketson

Mike Baltes

County Connection

Rick Ramacier

Scott Mitchell

Ruby Horta

Rashidi Barnes

Elmer Estimo

BAE Systems

Greg Marx

Marcus Jackson

Gillig

Josh Freeman

WAVE

Mike Masquelier

Marcellus Harper 


\section{Acronyms and Abbreviations}

AC

ATA VMRS

BEB

Btu

$\mathrm{CNG}$

dge

DOE

DOT

ESS

FCEB

FTA

$\mathrm{ft}$

gal

gge

GPS

hp

HVAC

KMBRC

$\mathrm{kW}$

$\mathrm{kWh}$

$\mathrm{lb}$

Low-No

MBRC

$\mathrm{mi}$

mpdge

NFCBP

NREL

NTD

OCTA

OEM

OST-R

$\mathrm{PMI} / \mathrm{PM}$

$\mathrm{RC}$

rpm

SI

SOC

TIGGER

ZEB alternating current

American Trucking Association Vehicle Maintenance Reporting Standards

battery electric bus

British thermal units

compressed natural gas

diesel gallon equivalent

U.S. Department of Energy

U.S. Department of Transportation

energy storage system

fuel cell electric bus

Federal Transit Administration

feet

gallon

gasoline gallon equivalent

global positioning system

horse power

heating, ventilation, and air conditioning

kilometers between roadcall

kilowatt

kilowatt hour

pound

Low or No Emission Vehicle Deployment Program

miles between roadcall

mile

miles per diesel gallon equivalent

National Fuel Cell Bus Program

National Renewable Energy Laboratory

National Transit Database

Orange County Transportation Authority

original equipment manufacturer

DOT's Research, Development, and Technology Office

preventive maintenance inspections

roadcall

revolutions per minute

International System of Units

state of charge

Transit Investments for Greenhouse Gas and Energy Reduction

zero-emission bus 


\section{Glossary}

Availability: The number of days the buses are actually available compared to the days that the buses are planned for operation, expressed as percent availability.

Clean point: For each evaluation, NREL works with the project partners to determine a starting point - or clean point - for the data analysis period. The clean point is chosen to avoid some of the early and expected operations problems with a new vehicle going into service, such as early maintenance campaigns. In some cases, reaching the clean point may require 3 to 6 months of operation before the evaluation can start. This applies to new technology buses as well as conventional buses.

Deadhead: The miles and hours that a vehicle travels when out of revenue service with no expectation of carrying revenue passengers. Deadhead includes leaving or returning to the garage or yard facility and changing routes.

Miles between roadcalls (MBRC): A measure of reliability calculated by dividing the number of miles traveled by the total number of roadcalls, also known as mean distance between failures. MBRC results in the report are categorized as follows:

- Bus MBRC: Includes all chargeable roadcalls. Includes propulsion-related issues as well as problems with bus-related systems such as brakes, suspension, steering, windows, doors, and tires.

- Propulsion-related MBRC: Includes roadcalls that are attributed to the propulsion system. Propulsion-related roadcalls can be caused by issues with the transmission, batteries, and electric drive.

- Energy storage system (ESS)-related MBRC: Includes roadcalls attributed to the energy storage system only (specific to BEBs).

- Fuel cell system-related MBRC: Includes roadcalls attributed to the fuel cell and balance of plant only (specific to FCEBs).

Revenue service: The time when a vehicle is available to the general public with an expectation of carrying fare-paying passengers. Vehicles operated in a fare-free service are also considered revenue service.

Roadcall: A failure of an in-service bus that causes the bus to be replaced on route or causes a significant delay in schedule. The analysis includes chargeable roadcalls that affect the operation of the bus or may cause a safety hazard. Non-chargeable roadcalls can be passenger incidents that require the bus to be cleaned before going back into service, or problems with an accessory such as a farebox or radio. 


\section{Executive Summary}

The U.S. Department of Transportation's (DOT's) Federal Transit Administration (FTA) supports the research, development, and demonstration of low- and zero-emission technology for transit buses. FTA funds research projects with a goal of facilitating commercialization of advanced technologies for transit buses that will increase efficiency and improve transit operations. DOT's Research, Development, and Technology Office (OST-R) also has an interest in zero-emission bus (ZEB) technology deployment and commercialization. OST-R is coordinating and collaborating with FTA on the evaluation process and results by providing funding to cover additional evaluations. FTA and OST-R are collaborating with the U.S. Department of Energy (DOE) and DOE's National Renewable Energy Laboratory (NREL) to conduct in-service evaluations of advanced technology buses developed under its programs. NREL uses a standard evaluation protocol for evaluating the advanced technologies deployed under the FTA programs.

FTA seeks to provide results from new technologies being adopted by transit agencies. The eight evaluations selected to date include battery electric buses (BEBs) and fuel cell electric buses (FCEBs) from different manufacturers operating in fleets located in both cold and hot climates. The purpose of this report is to present the results from Central Contra Costa Transit Authority (County Connection) deployment of four BEBs in Concord, California. NREL's evaluation of the BEBs at County Connection was funded by OST-R.

County Connections' service area covers more than 200 square miles in the East Bay of San Francisco area. In February 2017, the agency began operating a fleet of four BEBs in its service area. The battery buses are 29-ft trolley-replica buses built by Gillig with an electric propulsion system by BAE Systems. NREL is collecting data on two diesel bus fleets as baseline comparisons: seven model year 2014 Gillig diesel buses and three model year 2002 Gillig trolley-replica diesel buses. Because the older buses are operated on the same route as the BEBs, they are the best match in duty cycle, which is important for the fuel economy comparison.

County Connection operates its battery fleet on a free circulator route around Walnut Creek, California, with a layover stop at the Bay Area Rapid Transit (BART) station. The agency installed two charging stations: plug-in chargers at the facility for overnight charging and a WAVE inductive charging pad at the BART stop for wireless charging during scheduled layovers.

Table ES-1 provides a summary of the results for the County Connection battery fleet and baseline bus fleets. 
Table ES-1. Summary of County Connection Evaluation Results

\begin{tabular}{|c|c|c|c|}
\hline Data Item & Battery & Diesel & $\begin{array}{c}\text { Diesel (Trolley } \\
\text { Replica) }\end{array}$ \\
\hline Number of buses & 4 & 7 & 3 \\
\hline Total mileage in data period & 51,550 & 189,068 & - \\
\hline Average monthly mileage per bus & 1,074 & 2,251 & - \\
\hline Availability ( $85 \%$ is target) & 76.9 & 85.5 & - \\
\hline Fuel economy (kWh/mile) & 2.84 & - & - \\
\hline Fuel economy $\left(\mathrm{mpdge}^{\mathrm{b}}\right)$ & 13.3 & 5.1 & 3.5 \\
\hline Average speed, including stops $(\mathrm{mph})^{\mathrm{c}}$ & 6.0 & 14.8 & 6.0 \\
\hline Miles between roadcalls (MBRC)_-bus ${ }^{d}$ & 4,686 & 63,023 & - \\
\hline MBRC-propulsion system only ${ }^{d}$ & 6,444 & 189,068 & - \\
\hline Total maintenance cost $(\$ / \text { mile })^{\mathrm{e}}$ & 0.39 & 0.44 & - \\
\hline $\begin{array}{l}\text { Maintenance cost-propulsion system only } \\
(\$ / \text { mile })\end{array}$ & 0.10 & 0.14 & - \\
\hline
\end{tabular}

a Diesel trolley-replica buses used for fuel economy comparison only.

${ }^{\mathrm{b}}$ Miles per diesel gallon equivalent.

${ }^{\mathrm{C}}$ Based on scheduled revenue service.

d MBRC data cumulative through May 2018.

e Work order maintenance cost.

The battery bus availability varied from $67.9 \%$ to $88.9 \%$, with a fleet average of $76.9 \%$. The availability for the diesel buses varied from $83.6 \%$ to $89.9 \%$, with a fleet average of $85.5 \%$. The battery fleet experienced some early bus-side and infrastructure-side charging issues in the first 4 months of the evaluation. The agency worked closely with the manufacturers to address these early issues. Availability was much higher during the last 8 months with an average availability of $84.7 \%$.

The battery buses had an overall average efficiency of $2.84 \mathrm{kWh}$ per mile, which equates to a fuel economy of 13.3 miles per diesel gallon equivalent (mpdge). The fuel economy for the diesel buses averaged $5.1 \mathrm{mpdge}$ and for the diesel trolley buses it averaged $3.5 \mathrm{mpdge}$. The battery fleet's fuel economy was 3.8 times higher than that of the diesel trolley buses operated on the same service route and 2.6 times higher than that of the diesel buses operated on all the County Connection routes.

During the data period, County Connection paid an average of $\$ 0.22 / \mathrm{kWh}$ for electricity for the battery buses and $\$ 2.01 /$ gal for diesel fuel. The average fuel cost per mile for the battery fleet during the evaluation period was $\$ 0.73 / \mathrm{mi}$. The per-mile fuel costs for the diesel buses showed a steady increase during the evaluation period, from a low of $\$ 0.32 / \mathrm{mi}$ in July 2017 to a high of $\$ 0.48 / \mathrm{mi}$ in May 2018. The average was $\$ 0.40 / \mathrm{mi}$ for the diesel buses and $\$ 0.54 / \mathrm{mi}$ for the diesel trolley buses.

NREL also analyzed work order data to provide a comparison of maintenance costs between the battery fleet and the baseline fleet. After removing accident- and warranty-related items for all fleets, the average per-mile maintenance cost for the data period was $\$ 0.39 / \mathrm{mi}$ for the battery buses and $\$ 0.44 / \mathrm{mi}$ for the diesel buses. During the data period, the maintenance cost for the battery buses was $13 \%$ less than that of the diesel buses. 
NREL analyzed the maintenance data to determine costs by vehicle system. The systems with the highest percentage of maintenance costs for the battery buses and diesel buses were the same: 1) cab, body, and accessories; 2) propulsion-related; and 3) preventive maintenance inspections (PMI).

Issues and lessons learned for County Connection include the following.

Charger availability - When deploying a BEB fleet, availability of an on-route charger is critical for operation. Downtime of a charger results in downtime for the fleet. Early in this evaluation, County Connection experienced a couple issues with the inductive charger that decreased the battery fleet availability. Importantly, none of the issues were related to the electrical circuitry or wireless charging components; rather, the issues were related to ancillary cooling equipment. Investigation of the primary issue indicates that a lightning strike was likely the cause of the compressor failure.

Charger efficiency-During examination of the inductive charger performance, the manufacturer explained how the charger's cooling system for this particular installation was intentionally oversized to allow for up to $100 \%$ duty cycle charging because County Connection had prioritized reliability and system uptime over system efficiency. The manufacturer reported that major improvements have been made to the cooling system design of the inductive charger since this first-generation product, improving the efficiency of their higher power charger to $92 \%$ (typical) and avoiding issues experienced in the early months of this deployment.

Added operating costs - When adding BEBs with depot charging to a fleet, an agency needs to plan for logistics to plug in and move the buses to and from the charger at the depot. This is especially true for fleets that don't install a charger for each bus. County Connection reports that this adds labor costs to the project. Because the agency has two chargers to cover the fleet of four buses, staff are needed to stage and move the buses to ensure each one gets fully charged before parking overnight. Scaling up to a larger fleet will add complexity to this process. For BEBs with on-route charging, additional time may need to be planned into the route schedule. County Connection has added a half hour to the beginning and end of each operator shift to allow time for the BEBs to charge at the inductive charger prior to starting the route and before returning to the depot. This adds to the labor needs for operating BEBs. Some agencies may only experience one of these two impacts, but County Connection is operating both types of chargers and has decided to top off the charge of the buses on route and at the depot.

Maintenance costs - Because the BEBs are under warranty, some repairs were made that are not accounted for in the maintenance records. Labor and parts costs for repairs that are handled by the OEM are not typically included in maintenance data sets and NREL is unable to analyze and report on them. At this point in the demonstration, post-warranty maintenance costs are unknown. Agencies should carefully consider this when using early reported costs to plan for BEB fleet implementation and long-term maintenance costs.

Maintenance skill set - Deploying new technologies presents a challenge for transit staff to take over all maintenance responsibilities after the warranty period ends. Current staff do not have the skill set needed to fully maintain BEBs. Additional labor hours are incurred as staff come up to speed on the new technology. In addition, there is a shortage in the hiring pool of technicians 
with the desired skill sets. The industry is addressing this need by working with community colleges and technical schools to add the required courses for ZEB technicians. The updated training materials are still in the beginning stages of development, therefore current graduates do not yet have the needed skill set. Until these programs are fully established, hiring ZEB qualified technicians will be a challenge. 


\section{Table of Contents}

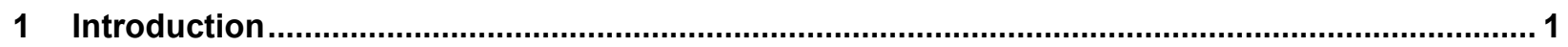

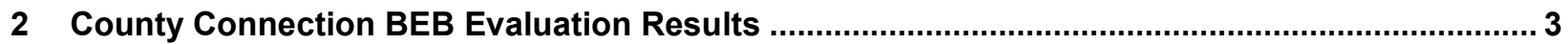

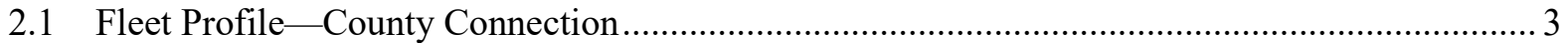

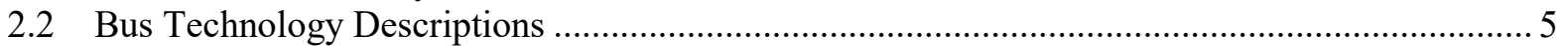

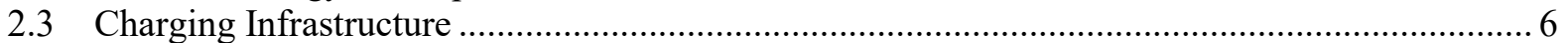

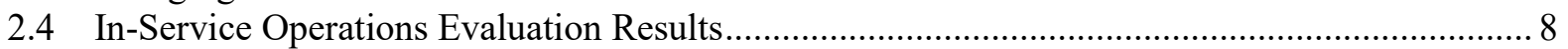

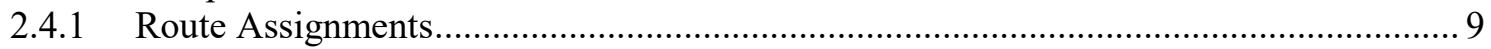

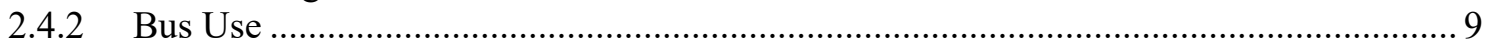

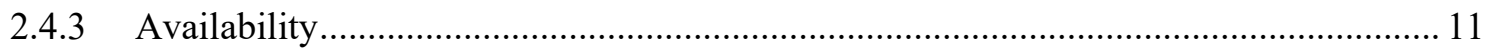

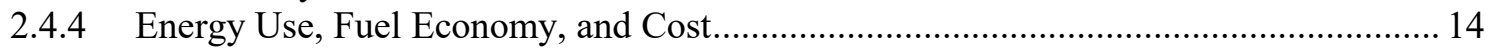

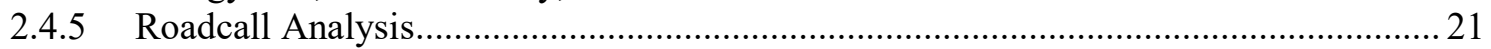

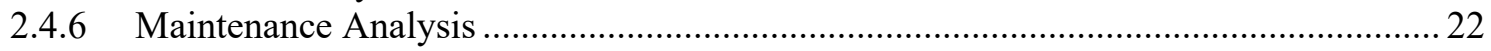

2.4.7 Total Work Order Maintenance Costs..................................................................... 22

2.4.8 Work Order Maintenance Costs Categorized by System ........................................... 24

2.4.9 Propulsion-Related Work Order Maintenance Costs ................................................... 27

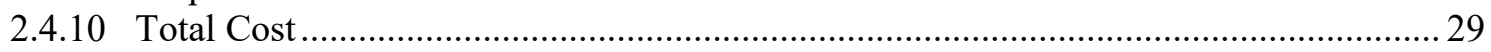

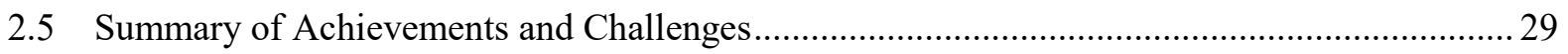

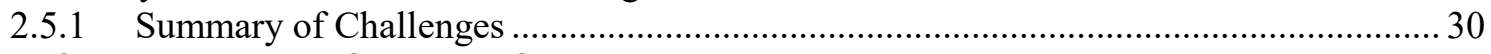

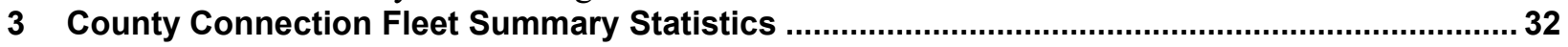

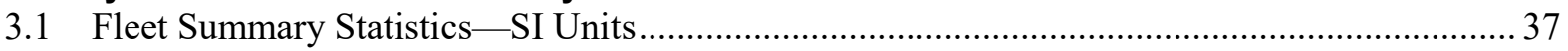

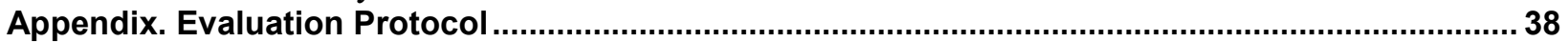




\section{List of Figures}

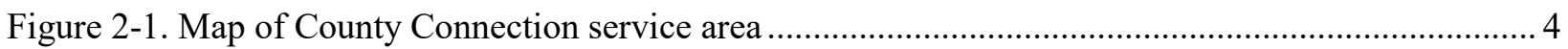

Figure 2-2. County Connection Gillig battery electric bus ................................................................... 5

Figure 2-3. Plug-in charger at the County Connection facility ............................................................... 7

Figure 2-4. WAVE inductive charging pad (left) and charging equipment (right) .................................. 8

Figure 2-5. Bus lined up to charge at the on-route WAVE charger........................................................ 8

Figure 2-6. Cumulative miles and hours for the battery bus fleet...................................................... 9

Figure 2-7. Average monthly miles per bus for the battery and diesel fleets ...................................... 10

Figure 2-8. Monthly availability and reasons for unavailability for the battery fleet and diesel fleet........ 12

Figure 2-9. Overall availability during the evaluation period .............................................................. 13

Figure 2-10. Monthly charges and monthly energy consumption for the battery fleet............................ 14

Figure 2-11. Fraction of plug-in charges by overall time of day ........................................................ 15

Figure 2-12. Average minimum SOC for plug-in and inductive charges ............................................... 16

Figure 2-13. Monthly fuel economy for the battery, diesel, and diesel trolley bus fleets.......................... 17

Figure 2-14. Monthly average fuel price for electricity and diesel fuel.................................................. 19

Figure 2-15. Monthly fuel cost per mile for the battery and diesel bus fleets ....................................... 20

Figure 2-16. Monthly utility energy, bus energy, and charging efficiency........................................... 21

Figure 2-17. Cumulative bus MBRC and propulsion-related MBRC..................................................... 22

Figure 2-18. Monthly scheduled and unscheduled maintenance cost per mile for the battery and diesel

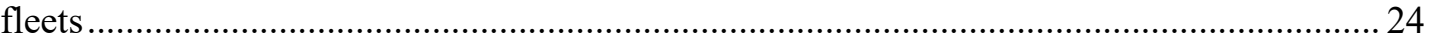

Figure 2-19. Monthly maintenance cost per mile by system for the BEB system (battery bus fleet and

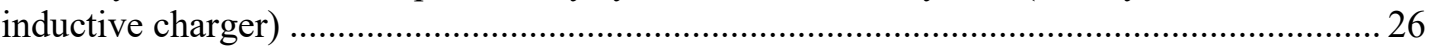

Figure 2-20. Monthly maintenance cost per mile by system for the diesel bus fleet...............................26

Figure 2-21. Monthly operations (maintenance and fuel) cost for the battery and diesel bus fleets .......... 29 


\section{List of Tables}

Table ES-1. Summary of County Connection Evaluation Results ........................................................ vii

Table 1-1. Selected Evaluation Projects ........................................................................................... 2

Table 2-1. System Descriptions for the Battery Electric, Diesel, and Diesel Trolley Buses ...................... 5

Table 2-2. Performance Metrics Analyzed for Each Fleet..................................................................... 6

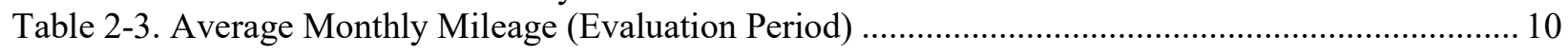

Table 2-4. Summary of Availability by Bus for Battery and Diesel Buses ........................................... 11

Table 2-5. Summary of Availability and Unavailability by Category ................................................. 14

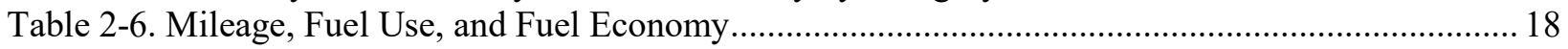

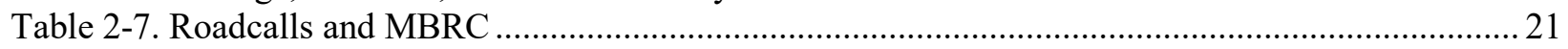

Table 2-8. Total Work Order Maintenance Costs .................................................................................... 23

Table 2-9. Work Order Maintenance Cost per Mile by System ${ }^{\mathrm{a}}$....................................................... 25

Table 2-10. Propulsion-Related Work Order Maintenance Costs by System...........................................2 28

Table 2-11. Overall Operations (Maintenance and Fuel) Cost per Mile...................................................2 29

Table 3-1. County Connection-Fleet Operations and Economics …...................................................... 32

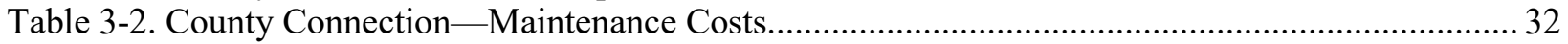

Table 3-3. County Connection - Breakdown of Maintenance Costs by System ...................................... 33

Table 3-4. County Connection-Fleet Operations and Economics (SI) ............................................... 37

Table 3-5. County Connection-Maintenance Costs (SI) ..................................................................... 37

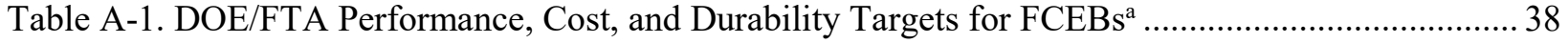




\section{Introduction}

The U.S. Department of Transportation's (DOT's) Federal Transit Administration (FTA) supports the research, development, and demonstration of low- and zero-emission technology for transit buses. FTA funds a number of research projects with a goal of facilitating commercialization of advanced technologies for transit buses that will increase efficiency and improve transit operations. These programs include the following:

- National Fuel Cell Bus Program (NFCBP)—a \$180 million, multi-year, cost-share research program for developing and demonstrating commercially viable fuel cell technology for transit buses.

- Transit Investments for Greenhouse Gas and Energy Reduction (TIGGER)— \$225 million for capital investments that would reduce greenhouse gas emissions and/or lower the energy use of public transportation systems.

- Low or No Emission Vehicle Deployment Program (Low-No)— \$271.35 million in funding (FY13-FY18) to transit agencies for capital purchases of zero-emission and lowemission transit buses that have been largely proven in testing and demonstration efforts but are not yet widely deployed.

FTA understands the need to share early experience of advanced technologies with the transit industry. FTA is funding evaluations of a selection of these projects to provide comprehensive, unbiased performance results from advanced technology bus development, operations, and implementation. These evaluations have proved useful for a variety of groups including transit operators considering the technology for future procurements, manufacturers needing to understand the status of the technology for transit applications, and government agencies making policy decisions or determining future research needs. The evaluations include economic, performance, and safety factors. Data are collected on the operation, maintenance, and performance of each advanced technology fleet and a comparable baseline fleet operating at the same site (if available).

FTA is collaborating with the U.S. Department of Energy (DOE) and DOE's National Renewable Energy Laboratory (NREL) to conduct in-service evaluations of advanced technology buses. For more than a decade, NREL has been evaluating advanced technology transit buses using a standard data collection and analysis protocol originally developed for DOE heavy-duty vehicle evaluations. Funding for these evaluations has come from several agencies including FTA, DOE, and the California Air Resources Board. NREL has evaluated fuel cell electric buses (FCEBs) as well as battery electric buses (BEBs) following this standard protocol. DOT's Research, Development, and Technology Office (OST-R) also has an interest in zeroemission bus (ZEB) technology deployment and commercialization. OST-R is coordinating and collaborating with FTA on the evaluation process and results by providing funding to cover additional evaluations.

NREL uses a set of criteria to prioritize the available projects for selection. The criteria include number of buses deployed, record-keeping practices of the transit agency, commitment level of the bus original equipment manufacturer (OEM), and the availability of appropriate baseline buses for comparison. The criteria are not intended to be rigid; however, the determination of 
priority is based on how many criteria are met. In consultation with FTA, NREL has selected several projects that are in the highest priority category. Other projects will be chosen as more information becomes available. Table 1-1 lists the projects selected for evaluation as of the publication date of this report.

Table 1-1. Selected Evaluation Projects

\begin{tabular}{|c|c|c|c|}
\hline $\begin{array}{c}\text { Site } \\
\#\end{array}$ & Transit Agency and Location & Project Description & $\begin{array}{c}\text { Evaluation } \\
\text { Status }\end{array}$ \\
\hline 1 & King County Metro, Seattle, WA & $\begin{array}{l}3 \text { Proterra } 40 \text {-ft Catalyst buses and } 1 \\
\text { fast-charge station }\end{array}$ & Completed \\
\hline 2 & Long Beach Transit, Long Beach, CA & $\begin{array}{l}10 \text { BYD } 40-\mathrm{ft} \text { BEBs, overnight charging } \\
\text { with } 1 \text { inductive charger on route }\end{array}$ & $\begin{array}{c}\text { Initiated April } \\
2017 \\
\end{array}$ \\
\hline 3 & $\begin{array}{l}\text { Central Contra Costa Transit } \\
\text { Authority, Concord, CA }\end{array}$ & $\begin{array}{l}4 \text { Gillig/BAE Systems } 29-\mathrm{ft} \text { BEBs, } \\
\text { overnight charging with } 1 \text { inductive } \\
\text { charger on route }\end{array}$ & Completed \\
\hline 4 & $\begin{array}{l}\text { Orange County Transportation } \\
\text { Authority, Santa Ana, CA }\end{array}$ & $\begin{array}{l}1 \text { American Fuel Cell Bus (AFCB): } \\
\text { BAE Systems, Ballard Power Systems, } \\
\text { and ENC }\end{array}$ & Completed \\
\hline 5 & $\begin{array}{l}\text { Stark Area Regional Transit Authority, } \\
\text { Camden, } \mathrm{OH}\end{array}$ & 7 AFCBs & $\begin{array}{c}\text { Initiated } \\
\text { August } 2017\end{array}$ \\
\hline 6 & $\begin{array}{l}\text { Massachusetts Bay Transportation } \\
\text { Authority, Boston, MA }\end{array}$ & $\begin{array}{l}1 \mathrm{AFCB} \text { with Nuvera PowerTap system } \\
\text { fueling infrastructure }\end{array}$ & Completed \\
\hline 7 & Duluth Transit, Duluth, MN & 6 Proterra 40-ft Catalyst E2 BEBs & $\begin{array}{c}\text { Initiated May } \\
2018\end{array}$ \\
\hline 8 & $\begin{array}{l}\text { Southeastern Pennsylvania } \\
\text { Transportation Authority, } \\
\text { Philadelphia, PA }\end{array}$ & 25 Proterra 40-ft Catalyst E2 BEBs & $\begin{array}{l}\text { Planned } \\
2019\end{array}$ \\
\hline
\end{tabular}

The purpose of this report is to present the results from the Central Contra Costa Transit Authority (County Connection) deployment of four BEBs in Concord, California. NREL's evaluation of the BEBs at County Connection was funded by OST-R. 


\section{County Connection BEB Evaluation Results}

In February 2017, County Connection began operating a fleet of four BEBs in its service area. This section summarizes the evaluation results for the battery buses in comparison to a selection of baseline buses. The focus of the analysis is on one year of data from June 2017 through May 2018.

\subsection{Fleet Profile-County Connection}

County Connection - formally known as Central Contra Costa Transit Authority-is a public transit agency that provides fixed-route and paratransit service in the San Francisco Bay Area. Headquartered in Concord, California, County Connection provides transit service to 11 surrounding jurisdictions, including Clayton, Concord, Danville, Lafayette, Martinez, Moraga, Orinda, Pleasant Hill, San Ramon, Walnut Creek, and unincorporated central Contra Costa County. The service area covers approximately 200 square miles and contains more than 482,000 residents. The agency operates 25 weekday routes (including 7 express routes) and 10 weekend routes with a fleet of 121 transit buses.

County Connection was awarded a grant from the FTA in 2012 as part of FTA's Clean Fuels Grant Program. The \$4.32 million grant was used to purchase four all-electric Gillig buses and two electric vehicle charging stations. The four trolley-replica electric buses operate on Route 4-a free circulator route through downtown Walnut Creek with a layover stop at the Bay Area Rapid Transit (BART) station. The buses replaced a fleet of diesel trolley replicas that had reached the end of their expected service life. FTA awarded a 2016 Low-No Program grant to County Connection to purchase four additional electric buses to expand the service. These buses were delivered in May and August 2018. Figure 2-1 shows a map of the County Connection service area with an inset showing the Walnut Creek route. 


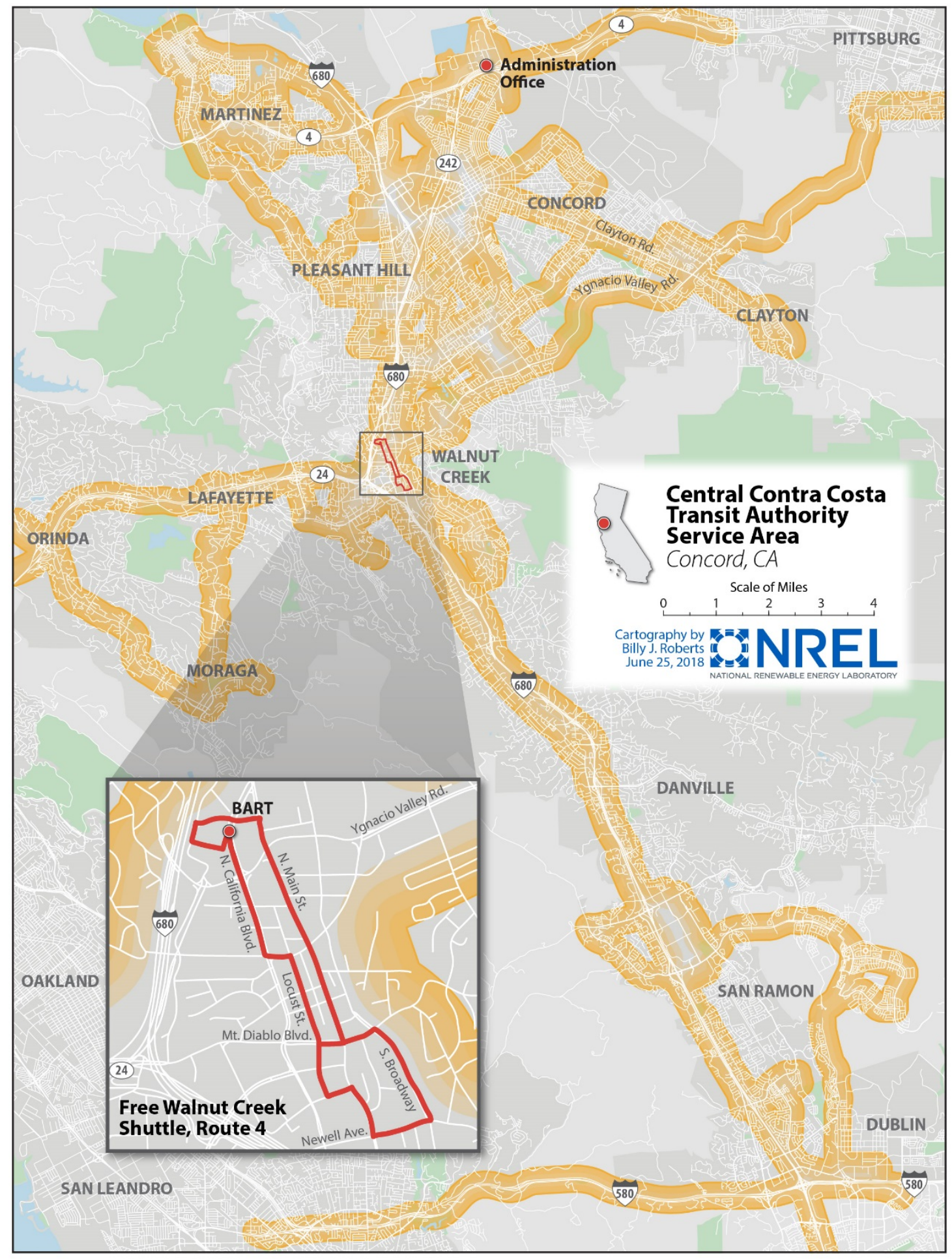

Figure 2-1. Map of County Connection service area 


\subsection{Bus Technology Descriptions}

County Connection's battery buses are 29-ft trolley-replica buses built by Gillig with a BAE Systems electric propulsion system. NREL is collecting data on two diesel bus fleets as baseline comparisons: a fleet of seven model year 2014 Gillig diesel buses and a fleet of three model year 2002 Gillig trolley-replica diesel buses. Table 2-1 provides selected specifications for each bus type. Figure 2-2 is a photo of one of the battery buses.

Table 2-1. System Descriptions for the Battery Electric, Diesel, and Diesel Trolley Buses

\begin{tabular}{|l|c|c|c|}
\hline \multicolumn{1}{|c|}{ Vehicle System } & Battery & Diesel & Diesel Trolley \\
\hline $\begin{array}{l}\text { Number of buses } \\
\text { in evaluation }\end{array}$ & 4 & 7 & 3 \\
\hline Bus manufacturer & Gillig & Gillig & Gillig \\
\hline Bus year and model & 2016 & $201429 \times 102$ & $200229 X 102$ \\
\hline Length (ft) & 29 & 29 & 29 \\
\hline GWWR (lb) & 34,500 & 30,000 & 30,000 \\
\hline Motor or engine & $\begin{array}{c}\text { BAE Systems, } \\
\text { HDS200 }\end{array}$ & $\begin{array}{c}\text { Diesel engine, } \\
\text { Cummins ISL-9 }\end{array}$ & $\begin{array}{c}\text { Diesel engine, } \\
\text { Cummins ISL-280 }\end{array}$ \\
\hline Rated power & $\begin{array}{c}160 \mathrm{~kW} \text { nominal, } \\
200 \mathrm{~kW} \text { peak } \\
\text { Xalt, nickel } \\
\text { manese cobalt, } \\
100 \mathrm{kWh}\end{array}$ & 280 hp @ 2,200 rpm & 280 hp @ 2,000 rpm \\
\hline Energy storage & Electric & Mechanical & None \\
\hline Accessories & $\begin{array}{c}\$, 053,689 \\
\text { Bus purchase cost }\end{array}$ & $\$ 459,935$ & Mechanical \\
\hline
\end{tabular}

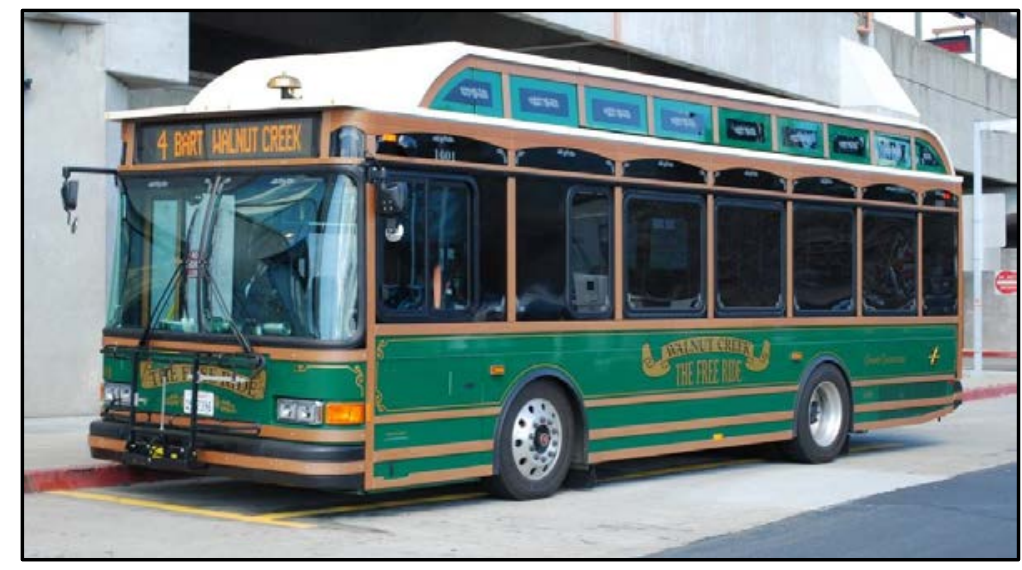

Figure 2-2. County Connection Gillig battery electric bus

One of NREL's goals in evaluating ZEBs is to document the performance and track progress over time toward meeting the technical targets. NREL collects data on conventional buses at each demonstration site for a baseline comparison. This is important primarily because fuel economy is highly dependent on duty cycle, but also because maintenance practices can be 
different from site to site. The best comparisons need to include buses operated in similar service at the same operating division. The most accurate comparison would be between buses of the same manufacturer, model, production year, and mileage. In that case, the only difference between the ZEB and baseline buses would be the propulsion system. This type of baseline comparison is not always possible.

The primary baseline comparison for this evaluation is the fleet of model year 2014 diesel buses. This conventional bus fleet is County Connection's best match to the battery bus fleet with respect to size and age. These buses are randomly dispatched on all routes and therefore have a different duty cycle than the battery buses operating only on the Walnut Creek route. The older diesel trolley-replica buses have been operated on the Walnut Creek route since 2002 and therefore are the best match to the battery buses in duty cycle, which is important for the fuel economy comparison. Table 2-2 outlines the different fleets in the analysis and indicates which performance metrics are included in the results.

Table 2-2. Performance Metrics Analyzed for Each Fleet

\begin{tabular}{|l|c|c|c|}
\hline \multicolumn{1}{|c|}{ Performance Metric } & Battery & Diesel & $\begin{array}{c}\text { Diesel } \\
\text { Trolley }\end{array}$ \\
\hline Monthly Mileage & $\mathbf{X}$ & $\mathbf{X}$ & \\
\hline Availability & $\mathbf{X}$ & $\mathbf{X}$ & \\
\hline Fuel Economy & $\mathbf{X}$ & $\mathbf{X}$ & $\mathbf{X}$ \\
\hline Fuel Cost per Mile & $\mathbf{X}$ & $\mathbf{X}$ & $\mathbf{X}$ \\
\hline Reliability (MBRC) & $\mathbf{X}$ & $\mathbf{X}$ & \\
\hline Maintenance Cost per Mile & $\mathbf{X}$ & $\mathbf{X}$ & \\
\hline
\end{tabular}

\subsection{Charging Infrastructure}

The agency installed two charging stations: plug-in chargers at the facility for overnight charging and a WAVE inductive charging pad at the BART stop on the Walnut Creek route for wireless charging during scheduled layovers. Figure 2-3 shows the plug-in charger installed at the County Connection facility. The agency typically plugs in the buses every night. The average charging time for the plug-in charger was 126 minutes, and each bus charged an average of less than once per day. There are two plug-in chargers at the facility for charging the four buses. 


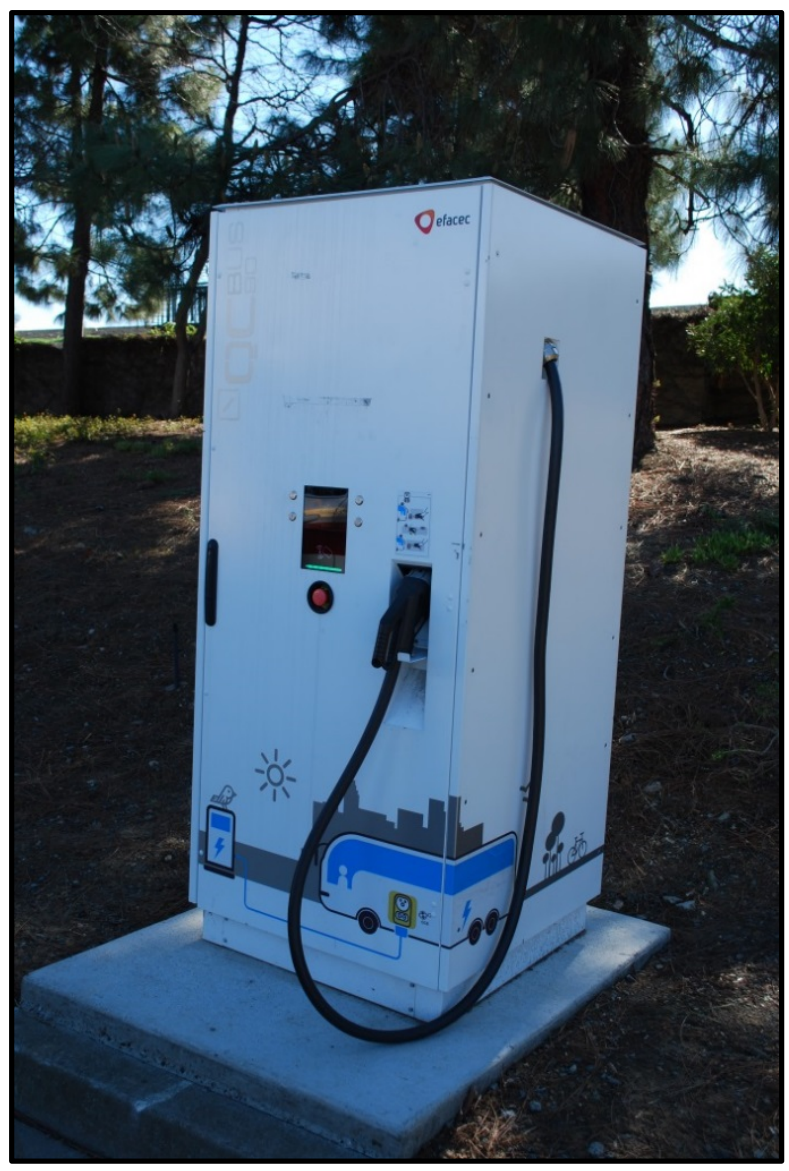

Figure 2-3. Plug-in charger at the County Connection facility

The 50-kW WAVE charger uses inductive power transfer between a power-transmitting plate embedded in the road surface and a receiving plate mounted to the bottom of the bus. ${ }^{1}$ Figure $2-4$ shows the inductive charging pad installed in the pavement and the WAVE charging equipment located nearby. The painted lines on the concrete help the operator align the bus for charging. An indicator in the driver's area provides additional feedback to let the driver know when the pads are aligned. Figure 2-5 shows a bus aligned for charging. Drivers are not allowed to back up the bus at the stop - if the alignment is not within accepted tolerance, they are required to drive around the circle to approach the charger again. The average charging time for the inductive charger was 6.9 minutes per bus, and each battery bus charged an average of about 12 times per day.

\footnotetext{
${ }^{1}$ WAVE news web page: https://waveipt.com/news/.
} 


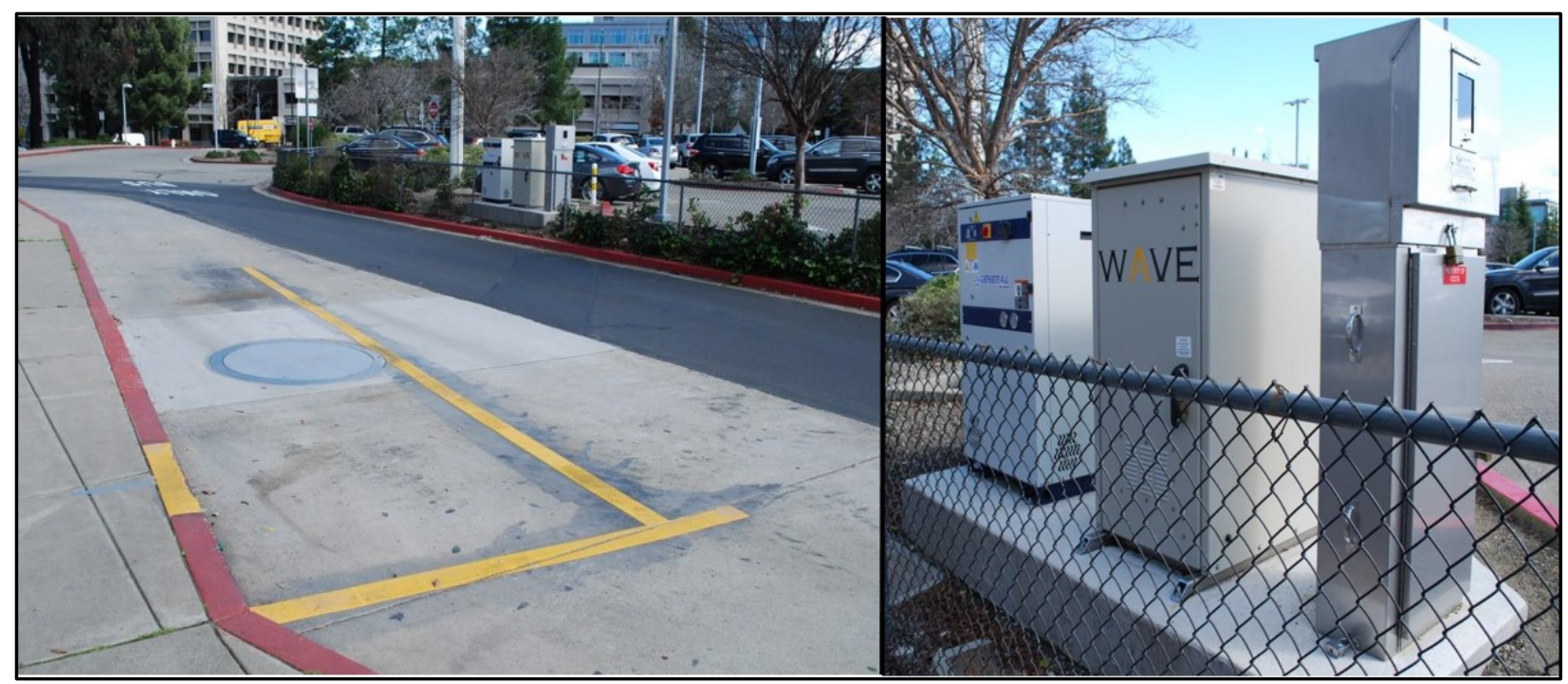

Figure 2-4. WAVE inductive charging pad (left) and charging equipment (right)

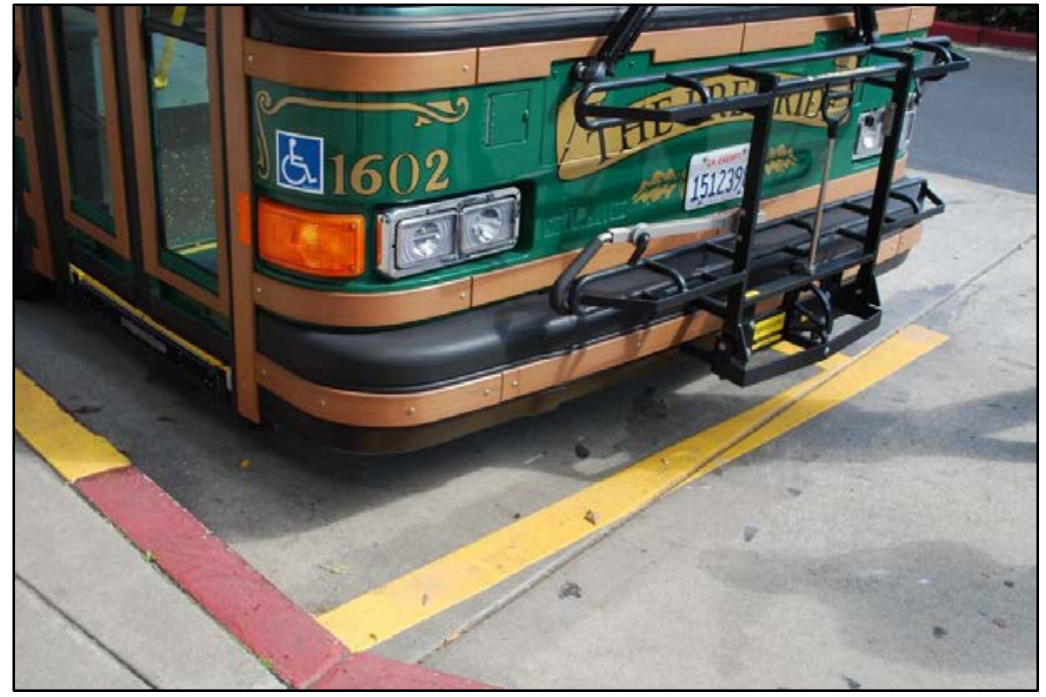

Figure 2-5. Bus lined up to charge at the on-route WAVE charger

\subsection{In-Service Operations Evaluation Results}

This section focuses on the results of a full year of operation from June 2017 through May 2018 (the evaluation period). County Connection began operating the battery buses in January 2017.

The diesel trolley fleet had been operating since 2002 and was now being replaced in service by the new battery fleet.

NREL kicked off the evaluation in February 2017 and began coordinating with County Connection for data collection. After acquiring all necessary data files for the monthly analysisincluding utility bills for both chargers-NREL established a clean point of June 2017 for the evaluation. 


\subsubsection{Route Assignments}

County Connection operates the battery buses on the Walnut Creek free shuttle route (route 4), which is a three-mile circulator through downtown Walnut Creek with a layover at the BART station. Full service requires three buses. The battery buses use the wireless inductive charger during every scheduled layover at the BART stop. The average speed for the Walnut Creek route based on scheduled revenue service is $6.0 \mathrm{mph}$, which does not include deadhead or out of service miles. The new battery buses are replacing the old diesel trolleys, which are past their expected service life. The diesel trolleys are still used as substitutes for the battery buses on route 4 if needed.

The baseline diesel buses are randomly dispatched on all routes from the County Connection facility, as displayed in the service map, Figure 2-1. This results in a faster average speed of 15.2 $\mathrm{mph}$. These average speeds are calculated using revenue service schedules and do not include deadhead or out of service miles.

\subsubsection{Bus Use}

Figure 2-6 tracks the accumulated mileage and operating hours of the battery buses since they were placed into service. County Connection has been operating the battery buses continuously since January 2017, accumulating over 65,000 total fleet miles after approximately one and a half years. The average overall speed, including all hours of operation for the buses (revenue service or otherwise), is $4.0 \mathrm{mph}$.

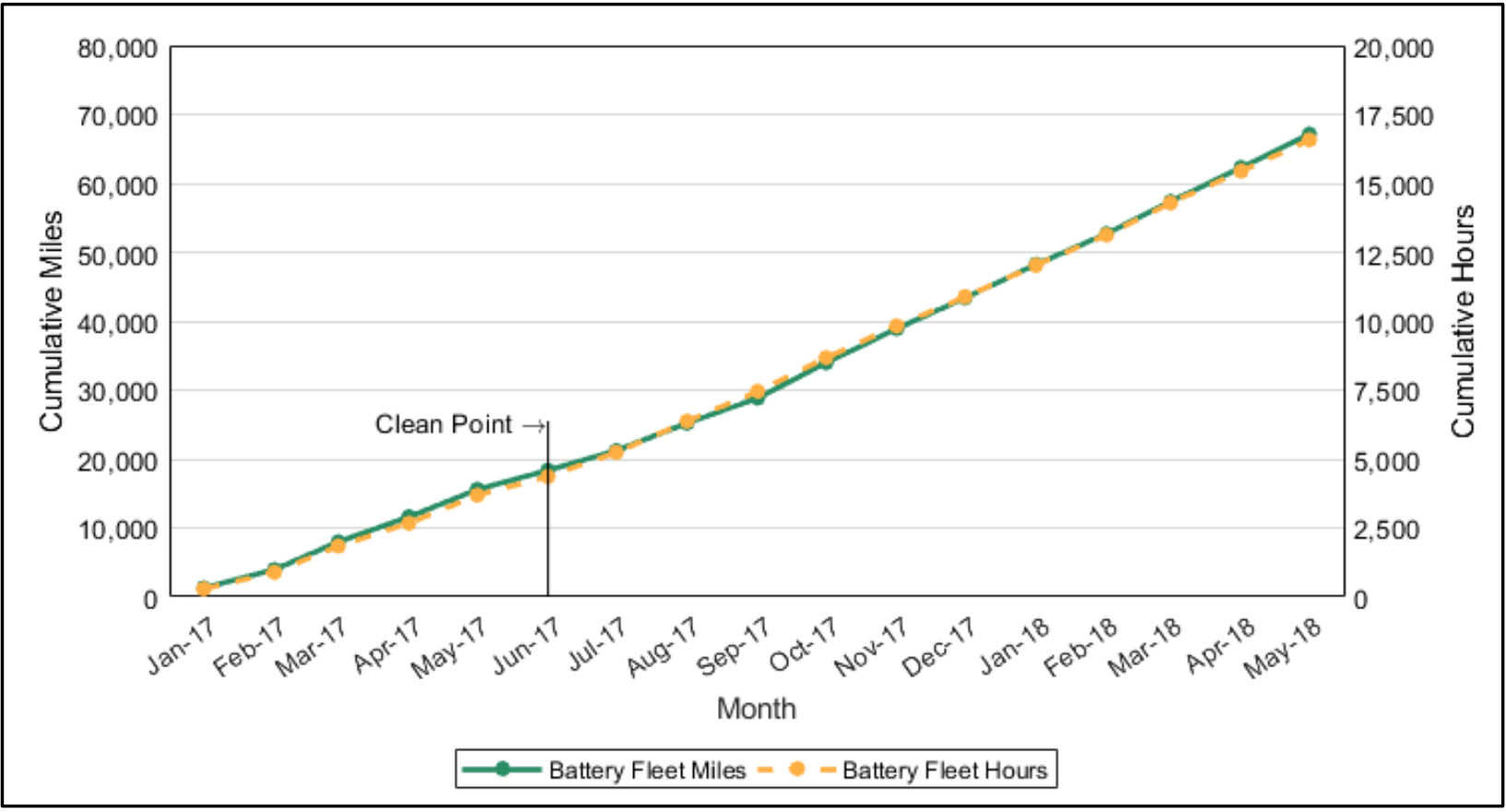

Figure 2-6. Cumulative miles and hours for the battery bus fleet

Table 2-3 provides the evaluation period mileage for each bus and the average monthly mileage by bus type, which is also displayed in Figure 2-7. The battery buses averaged between 950 and 1,300 miles per month, with an overall fleet average of 1,074 monthly miles per bus. This is lower than the baseline diesel bus fleet average of 2,251 monthly miles per bus. This difference 
is a result of the planned operation of these fleets. The battery fleet is restricted to the Walnut Creek circulator route while the diesel fleet is randomly dispatched on all routes, including commuter routes with higher speeds, which allows faster mileage accumulation.

Table 2-3. Average Monthly Mileage (Evaluation Period)

\begin{tabular}{|c|c|c|c|}
\hline Bus \# & $\begin{array}{c}\text { Total } \\
\text { Mileage }\end{array}$ & Months & $\begin{array}{c}\text { Average } \\
\text { Monthly } \\
\text { Mileage }\end{array}$ \\
\hline 1600 & 15,289 & 12 & 1,274 \\
\hline 1601 & 11,486 & 12 & 957 \\
\hline 1602 & 11,697 & 12 & 975 \\
\hline 1603 & 13,079 & 12 & 1,090 \\
\hline Battery fleet & $\mathbf{5 1 , 5 5 0}$ & $\mathbf{4 8}$ & $\mathbf{1 , 0 7 4}$ \\
\hline 1400 & 23,152 & 12 & 1,929 \\
\hline 1401 & 22,176 & 12 & 1,848 \\
\hline 1402 & 27,834 & 12 & 2,320 \\
\hline 1403 & 27,150 & 12 & 2,263 \\
\hline 1404 & 29,269 & 12 & 2,439 \\
\hline 1405 & 27,875 & 12 & 2,323 \\
\hline 1406 & 31,612 & 12 & 2,634 \\
\hline Diesel fleet & $\mathbf{1 8 9 , 0 6 8}$ & $\mathbf{8 4}$ & $\mathbf{2 , 2 5 1}$ \\
\hline
\end{tabular}

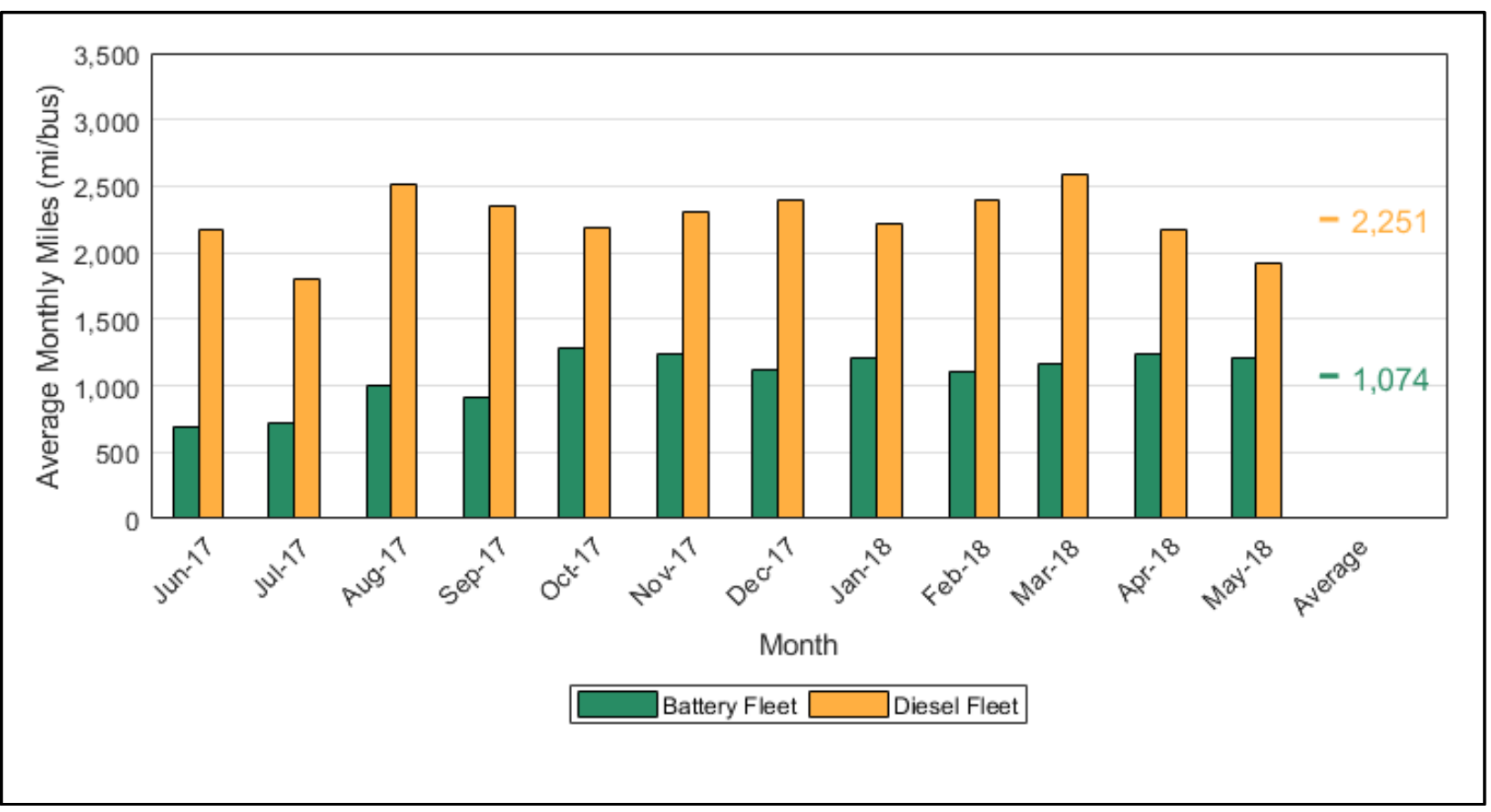

Figure 2-7. Average monthly miles per bus for the battery and diesel fleets 


\subsubsection{Availability}

County Connection plans the BEBs for operation 7 days per week; the diesel baseline buses are planned for weekdays only. The availability analysis summarizes reporting from County Connection on the daily status of the four battery buses and seven diesel buses in the evaluation. The daily reports indicated whether each bus was planned for service, whether the bus was available for service, and, if not available, indicated a reason that the bus was unavailable. This analysis does not show the fraction of time the buses were actually used in revenue service, only whether they were available for service at the time of morning pull-out. Thus, buses could have been available and not used, or available but used for other purposes such as training or special events. In addition, availability numbers do not necessarily reflect all day operation. There may be instances when a bus was removed from service after being available at morning pull-out, as well as instances when a bus that was unavailable at morning pull-out became available for service later the same day and may or may not have been used. The frequency of these scenarios was not tracked or included in the analysis. Their impacts on the fleet availability are expected to be small and have the effect of offsetting each other.

NREL analyzed the primary reasons for buses being held out of service and grouped them into the unavailability categories shown in the availability charts below. The bus maintenance category applies to all general maintenance issues not specific to a powertrain. Other categories include preventive maintenance (PM), electric drive system, energy storage system (ESS), bus charging issues, inductive charger issues, transmission, and engine. Many of the categories are only applicable to the battery bus fleet and others are only applicable to the diesel bus fleet.

The analysis covers 12 months of data collection-June 2017 through May 2018. Table 2-4 provides a summary of the overall availability for each of the battery and diesel buses during the evaluation period. The availability for the diesel buses varied from $78.6 \%$ to $89.9 \%$, with a fleet average of $85.5 \%$. The battery bus availability varied from $67.3 \%$ to $88.9 \%$, with a fleet average of $76.9 \%$.

Table 2-4. Summary of Availability by Bus for Battery and Diesel Buses

\begin{tabular}{|c|c|c|c|}
\hline Bus \# & $\begin{array}{c}\text { Planned } \\
\text { Days }\end{array}$ & $\begin{array}{c}\text { Available } \\
\text { Days }\end{array}$ & $\begin{array}{c}\text { Percent } \\
\text { Availability }\end{array}$ \\
\hline 1600 & 334 & 297 & $88.9 \%$ \\
\hline 1601 & 336 & 226 & $67.3 \%$ \\
\hline 1602 & 337 & 239 & $70.9 \%$ \\
\hline 1603 & 337 & 271 & $80.4 \%$ \\
\hline Battery fleet & $\mathbf{1 , 3 4 4}$ & $\mathbf{1 , 0 3 3}$ & $\mathbf{7 6 . 9 \%}$ \\
\hline 1400 & 336 & 281 & $83.6 \%$ \\
\hline 1401 & 336 & 264 & $78.6 \%$ \\
\hline 1402 & 336 & 302 & $89.9 \%$ \\
\hline 1403 & 336 & 282 & $83.9 \%$ \\
\hline 1404 & 336 & 293 & $87.2 \%$ \\
\hline 1405 & 336 & 290 & $86.3 \%$ \\
\hline 1406 & 336 & 300 & $89.3 \%$ \\
\hline Diesel fleet & $\mathbf{2 , 3 5 2}$ & $\mathbf{2 , 0 1 2}$ & $\mathbf{8 5 . 5 \%}$ \\
\hline
\end{tabular}


Figure 2-8 tracks the monthly average availability for the battery bus fleet and the diesel bus fleets as solid lines along the top of the chart. These represent the availability for bus-related issues only. Also included in the chart is a dashed line for "BEB System" availability, which accounts for infrastructure-related downtime for the battery bus fleet as well as individual bus issues.

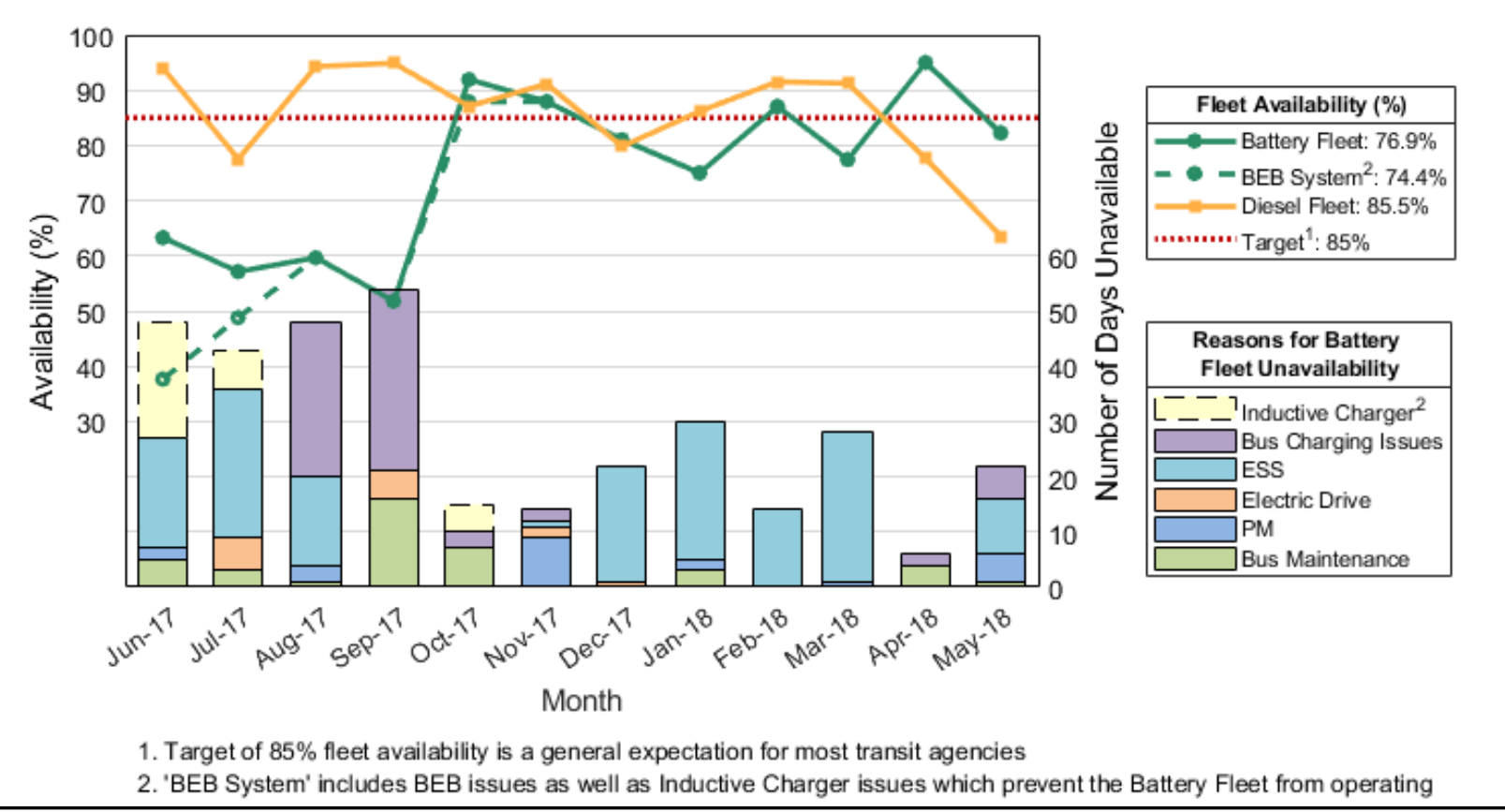

Figure 2-8. Monthly availability and reasons for unavailability for the battery fleet and diesel fleet

The battery fleet experienced some early bus-side and infrastructure-side charging issues in the first 4 months of the evaluation, during which the average fleet availability was $57.9 \%$. The battery fleet experienced issues with the battery management system for the high-voltage batteries. Software updates appear to have solved the issue. Downtime for charging equipment can have a significant effect on availability because it limits use of the entire battery bus fleet. This is particularly true for a small fleet deployment that relies on a single on-route charger. None of the inductive charging issues experienced by County Connection were related to the electrical circuitry or charging pads of the inductive charger; the downtime was a result of issues with ancillary equipment used for cooling (discussed in more detail in the Summary of Achievements and Challenges section below). County Connection worked closely with WAVE to address the early charging issues. County Connection achieved an average availability of $84.7 \%$ for the battery fleet during the remaining 8 months of the evaluation.

The stacked columns in Figure 2-8 show the number of days that the battery buses were unavailable, organized into six categories. Five of the categories-general bus maintenance, PM, electric drive system, ESS and bus charging issues-are all related to bus maintenance issues. The sixth category, inductive charger, accounts for all additional downtime from infrastructurerelated issues that caused the battery bus fleet to be unavailable. It is important to note that none of the infrastructure downtime was caused by issues with the charging circuitry or charging pads of the inductive charger; it was all related to ancillary equipment. In June and July of 2017, the downtime was a result of the chiller not functioning. After an inspection, it was reported to 
WAVE that the failure was caused by a power surge typical of a lightning strike. In October 2017, low coolant level caused a system shutdown and led to the replacement of an external cooling line. Most of the bus-side downtime during the evaluation period was due to issues in the ESS category, primarily with the battery management system. The battery fleet had very little downtime related to PM or other general maintenance issues.

The pie charts in Figure 2-9 show the percentage of days the buses in each fleet were available for service during the evaluation period. The fraction of unavailable days is divided into unavailability categories based on the reasons the buses were out of service. Downtime for the diesel fleet was split relatively evenly between engine maintenance (5.6\%), PM (4.0\%), and other general bus maintenance (4.6\%). For the battery fleet, a large fraction of downtime$12.0 \%$ of total planned service time-was due to issues with the ESS. The second largest category was bus-related charging issues, accounting for $5.5 \%$ of planned service time. Downtime for infrastructure-related charging issues represented $2.5 \%$ of planned service time, less than for general bus maintenance. Table 2-5 corresponds to Figure 2-9 and provides a fleetlevel breakdown of the availability percentages for each category.

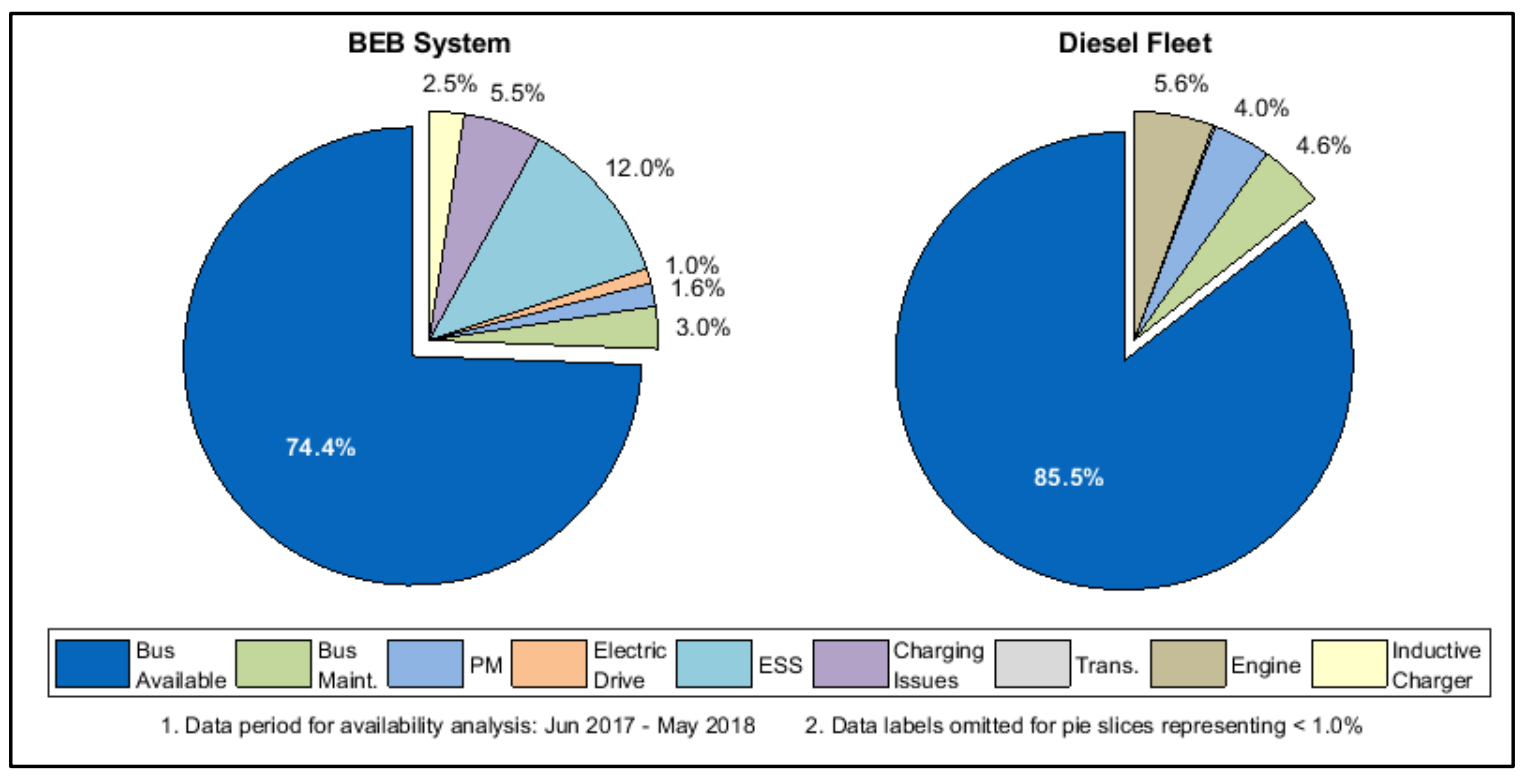

Figure 2-9. Overall availability during the evaluation period 
Table 2-5. Summary of Availability and Unavailability by Category

\begin{tabular}{|l|c|c|c|c|c|c|}
\hline \multicolumn{1}{|c|}{ Category } & $\begin{array}{c}\text { BEB } \\
\text { System } \\
\text { \# Days }\end{array}$ & $\begin{array}{c}\text { BEB } \\
\text { System } \\
\%\end{array}$ & $\begin{array}{c}\text { Battery } \\
\text { Fleet } \\
\text { \# Days }\end{array}$ & $\begin{array}{c}\text { Battery } \\
\text { Fleet } \\
\%\end{array}$ & $\begin{array}{c}\text { Diesel } \\
\text { Fleet } \\
\text { \# Days }\end{array}$ & $\begin{array}{c}\text { Diesel } \\
\text { Fleet } \\
\%\end{array}$ \\
\hline Planned days & 1,344 & - & 1,344 & - & 2,352 & - \\
\hline Days available & 1,000 & 74.4 & 1,033 & 76.9 & 2,012 & 85.5 \\
\hline Unavailable & 344 & - & 311 & - & 340 & - \\
\hline Bus & 40 & 11.6 & 40 & 12.9 & 109 & 32.3 \\
\hline PM & 22 & 6.4 & 22 & 7.1 & 95 & 28.2 \\
\hline Electric drive & 14 & 4.1 & 14 & 4.5 & - & - \\
\hline ESS & 161 & 46.8 & 161 & 51.8 & - & - \\
\hline Charging issues & 74 & 21.5 & 74 & 23.8 & - & - \\
\hline Transmission & - & - & - & - & 4 & 1.2 \\
\hline Engine & - & - & - & - & 129 & 38.3 \\
\hline Inductive charger & 33 & 9.6 & - & - & - & - \\
\hline
\end{tabular}

\subsubsection{Energy Use, Fuel Economy, and Cost}

Figure 2-10 shows the battery fleet's monthly total number of plug-in and inductive charges as lines and the monthly total energy consumption by charge type as stacked columns. During the evaluation period, the number of inductive charges steadily increased from approximately 1,000 charges per month to more than 1,600 charges per month for the four-bus fleet. The monthly energy consumption for inductive charging varied between 5,400 kWh and 10,300 kWh, with a monthly average of $8,725 \mathrm{kWh}$. Plug-in charging behavior remained consistent throughout the evaluation period with averages of 105 charges per month and 2,658 $\mathrm{kWh}$ energy consumption per month. Inductive charges delivered $6.2 \mathrm{kWh}$ per charge, on average, while the plug-in charger added $25.4 \mathrm{kWh}$ back to the bus ESS.

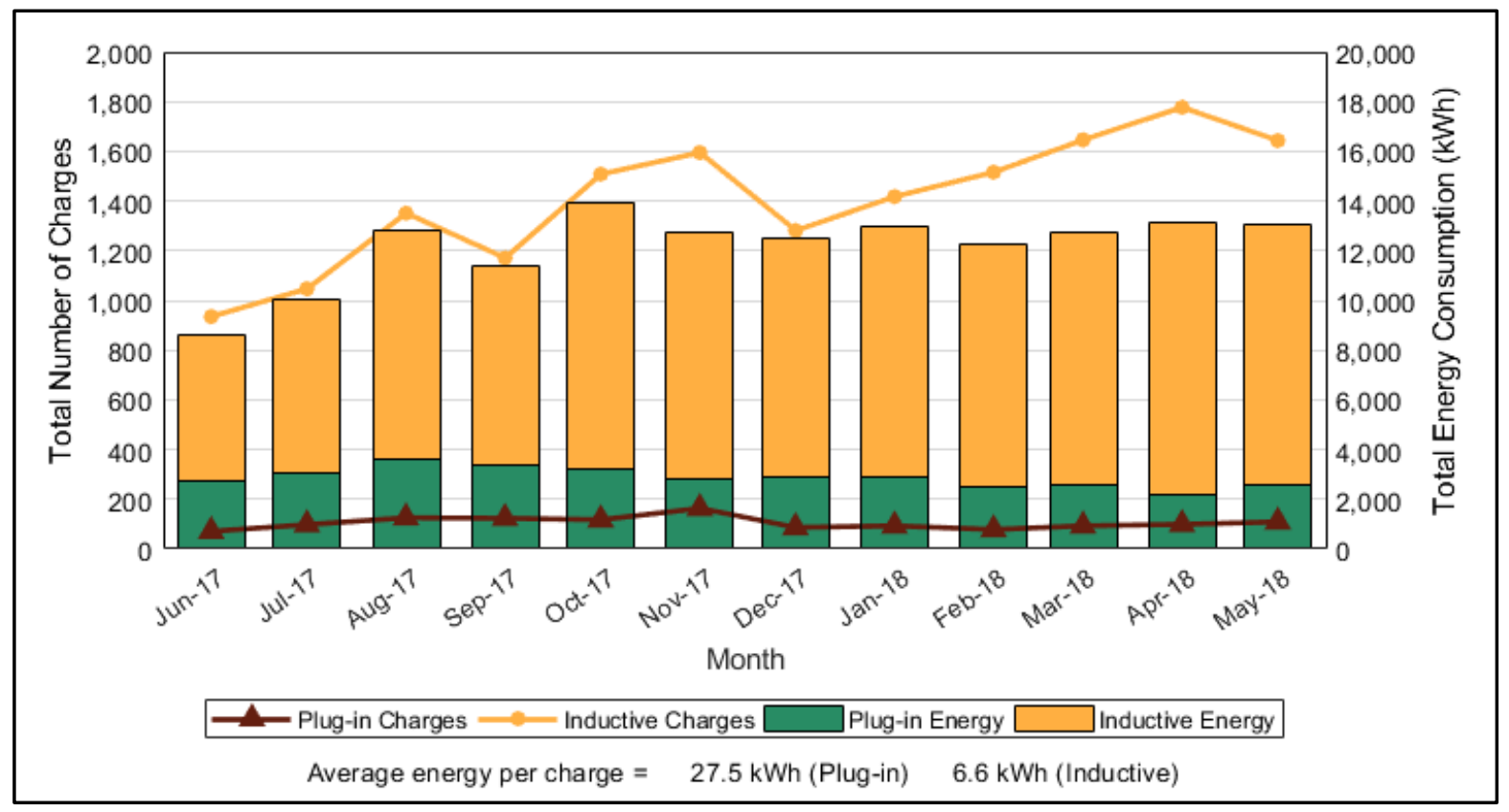

Figure 2-10. Monthly charges and monthly energy consumption for the battery fleet 
Plug-in charges could occur anytime a battery bus returned to County Connection's facility but occurred most often in the evening. NREL calculated the number of charges occurring in the morning (anytime between midnight and noon), afternoon (noon to 5 p.m.), and evening (5 p.m. to midnight). The fraction of plug-in charges for each time window is shown in Figure 2-11. Charges that began before midnight but extended into the next day were counted as $1 / 2$ charge in the evening and $1 / 2$ charge in the morning.

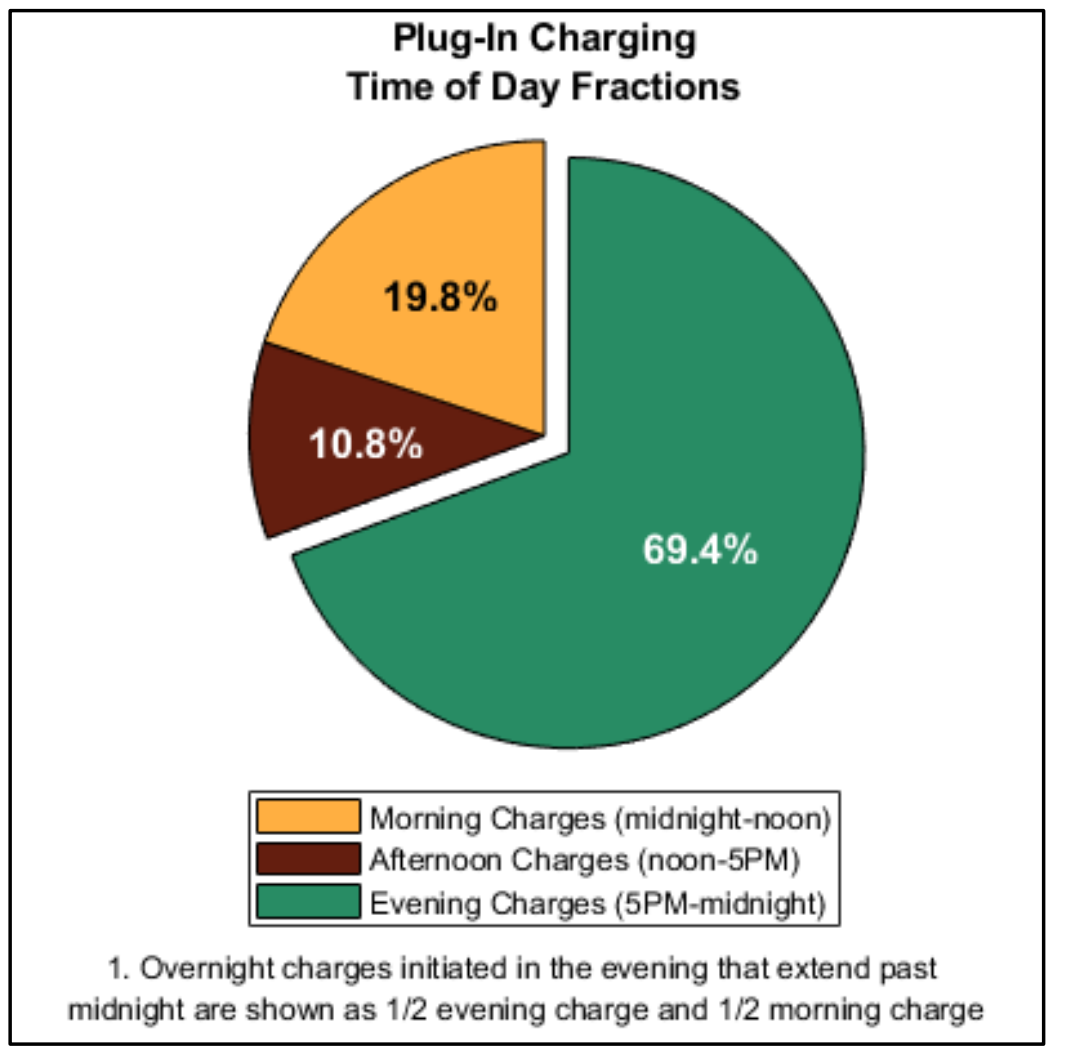

Figure 2-11. Fraction of plug-in charges by overall time of day

County Connection has planned the operation of the buses to keep the battery state of charge (SOC) above $60 \%$ to minimize degradation. Figure 2-12 shows the average minimum SOC at the beginning of a charge. The beginning SOC for the plug-in charges has remained consistent over the data period, with an overall average of $73.8 \%$. The beginning SOC for the inductive charging events has risen over time with an overall average of $73.6 \%$. 


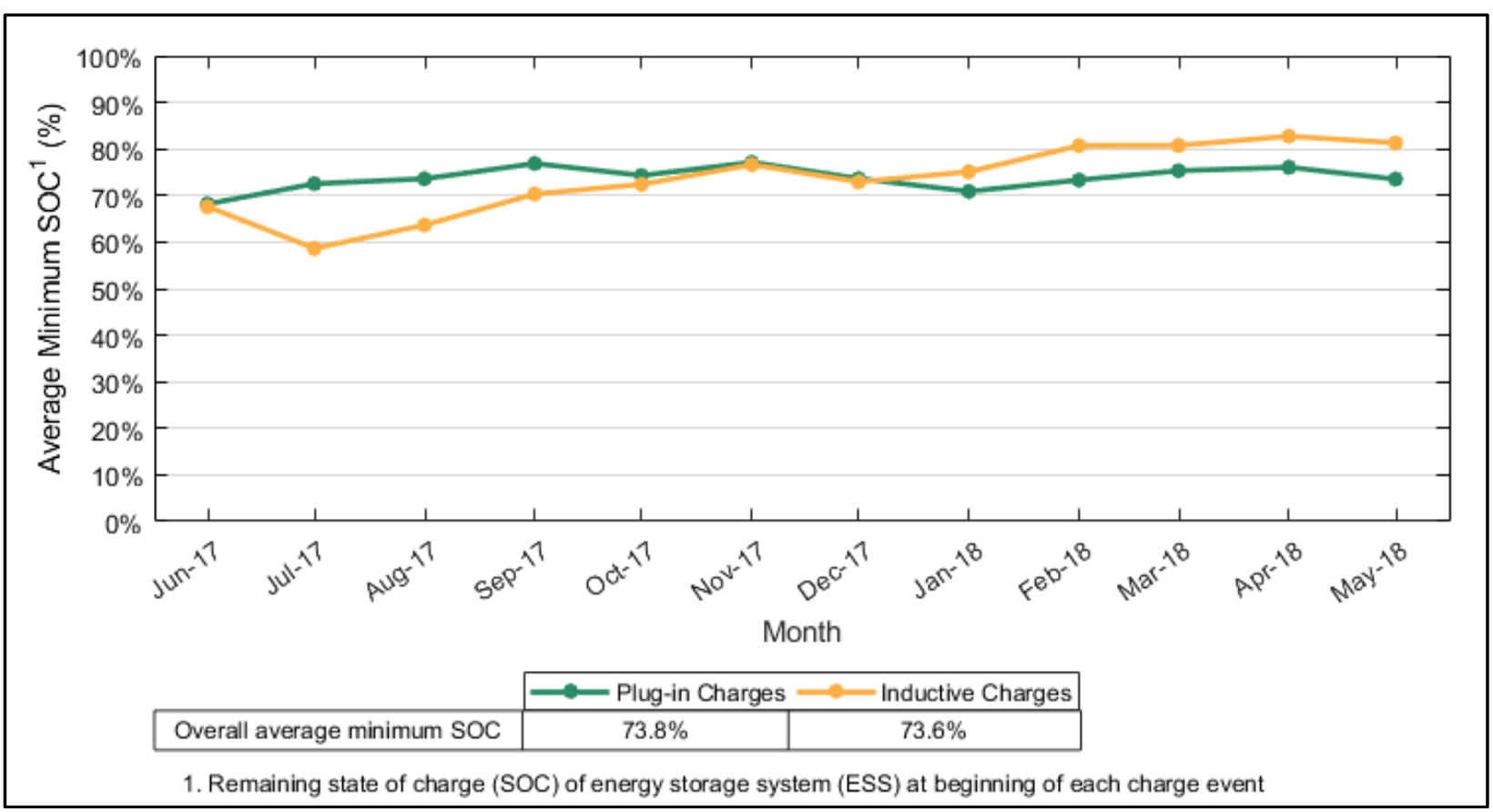

Figure 2-12. Average minimum SOC for plug-in and inductive charges

Figure 2-13 shows the monthly average fuel economy in miles per diesel gallon equivalent (mpdge) for the battery and diesel bus fleets. The electrical energy used by the battery buses was converted to diesel gallon equivalent (dge) using a conversion factor of $37.64 \mathrm{kWh} / \mathrm{dge}$. This energy conversion is detailed in the Appendix. Also plotted in Figure 2-13 is the average daily high temperature recorded at Buchanan Field Airport in Contra Costa County. ${ }^{2}$ The figure includes monthly fuel economy for both diesel baseline bus types. The standard diesel fleet is randomly dispatched on all routes. The overall system speed for County Connection is $14.8 \mathrm{mph}$ including express routes. The battery buses and diesel trolley buses operate on County Connection's slowest-speed route at $6.0 \mathrm{mph}$. Because it operates on the same route as the battery fleet (therefore at a similar speed), the diesel trolley fleet represents a better comparison of conventional bus fuel economy to battery bus fuel economy, despite the difference in age. NREL analyzed fuel economy data for the diesel trolley buses from 2002 to 2007 to ensure there was no significant age-related decline in average fuel economy for the fleet that would adversely impact this comparison. The year-to-year variation in weather is a primary factor in the difference in monthly average fuel economy; therefore, it is more appropriate to compare the diesel trolley fuel economy for the same time period than to compare the historical fuel economy trends.

The fuel economy for the two diesel fleets is very consistent during the evaluation period, averaging $5.1 \mathrm{mpdge}$ for the diesel buses and $3.5 \mathrm{mpdge}$ for the diesel trolley buses. The average fuel economy of the battery buses displays greater sensitivity to variation in ambient air temperature when the average high is above $80^{\circ} \mathrm{F}$. The lowest monthly fuel economy for the battery fleet (10.8 mpdge) occurred in July 2017, corresponding with the highest average daily high temperature of $93.7^{\circ} \mathrm{F}$. It's important to note that the ambient temperature is only one of the

\footnotetext{
${ }^{2}$ NOAA National Centers for Environmental Information-Climate Data Online, https://www.ncdc.noaa.gov/cdo$\underline{\text { web/. }}$.
} 
major factors influencing fuel economy. Route selection (average driving speed, driving intensity, stops per mile), passenger loading, traffic conditions, and operator driving habits can all have significant impact on fuel economy. The best monthly fuel economy was 14.6 mpdge, occurring in November 2017, and the overall average for the data period was 13.3 mpdge. The battery fleet's fuel economy is 3.8 times higher than that of the diesel trolley buses operated on the same service route and 2.6 times higher than that of the diesel buses operated on all the County Connection routes. Per-bus summaries of mileage, fuel consumption, and fuel economy are listed in Table 2-6.

County Connection reports that because of improvements in transmission and engine technologies, its newer diesel buses achieve an average fuel economy that is much higher compared to the older diesel trolley buses. The agency estimates that if these newer buses were operated on the Walnut Creek route, they would be expected to have a fuel economy higher than $3.5 \mathrm{mpg}$.

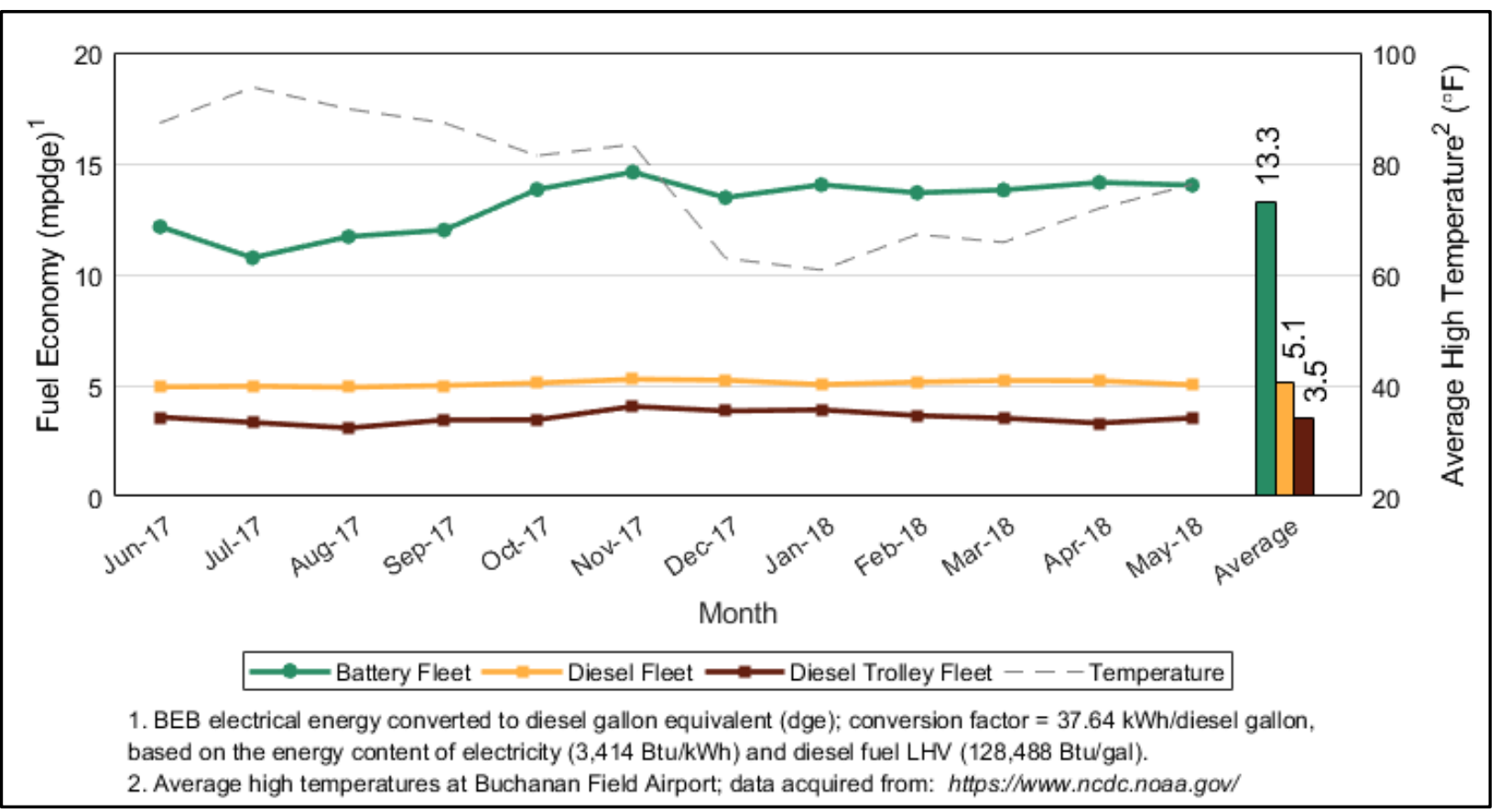

Figure 2-13. Monthly fuel economy for the battery, diesel, and diesel trolley bus fleets 
Table 2-6. Mileage, Fuel Use, and Fuel Economy

\begin{tabular}{|c|c|c|c|c|c|}
\hline Bus & $\begin{array}{c}\text { Mileage } \\
\text { (fuel } \\
\text { base) }\end{array}$ & $\begin{array}{c}\text { Fuel } \\
\text { Consumption } \\
\text { (kWh) }\end{array}$ & $\begin{array}{c}\text { Fuel } \\
\text { Consumption } \\
\text { (dge) }\end{array}$ & $\begin{array}{c}\text { Fuel Economy } \\
\text { (kWh/mi) }\end{array}$ & $\begin{array}{c}\text { Fuel Economy } \\
\text { (mpdge) }\end{array}$ \\
\hline 1600 & 15,289 & 44,806 & 1190.4 & 2.93 & 12.8 \\
\hline 1601 & 11,486 & 33,240 & 883.1 & 2.89 & 13.0 \\
\hline 1602 & 11,697 & 31,778 & 844.3 & 2.72 & 13.9 \\
\hline 1603 & 13,079 & 36,328 & 965.1 & 2.78 & 13.6 \\
\hline Battery fleet & $\mathbf{5 1 , 5 5 0}$ & $\mathbf{1 4 6 , 1 5 2}$ & $\mathbf{3 , 8 8 2 . 9}$ & $\mathbf{2 . 8 4}$ & $\mathbf{1 3 . 3}$ \\
\hline 1400 & 23,152 & - & $4,656.0$ & - & 5.0 \\
\hline 1401 & 22,176 & - & $4,431.3$ & - & 5.0 \\
\hline 1402 & 27,834 & - & $5,467.9$ & - & 5.1 \\
\hline 1403 & 27,150 & - & $5,486.3$ & - & 4.9 \\
\hline 1404 & 29,269 & - & $5,640.7$ & - & 5.2 \\
\hline 1405 & 27,875 & - & $5,519.1$ & - & 5.1 \\
\hline 1406 & 31,612 & - & $5,944.7$ & - & 5.3 \\
\hline Diesel fleet & $\mathbf{1 8 9 , 0 6 8}$ & - & $\mathbf{3 7 , 1 4 6}$ & - & $\mathbf{5 . 1}$ \\
\hline
\end{tabular}

Figure 2-14 compares the average monthly price for each fleet's transportation fuel—electricity for the battery fleet and diesel fuel for the baseline diesel fleet. Because these fuels use different native units, the chart shows the price per dge on the left axis and the equivalent price per $\mathrm{kWh}$ on the right axis. The relationship between the energy content of one gallon of diesel fuel and one $\mathrm{kWh}$ of electricity is detailed in Appendix $\mathrm{C}$. The average price of diesel fuel during the evaluation period was $\$ 2.01 / \mathrm{gal}$, compared to the average price for electricity of $\$ 0.22 / \mathrm{kWh}$ (\$8.39/dge). County Connection is not subject to electricity demand charges under the current rate schedule with their electric utility, PG\&E. It's clear that the price of electricity is much higher-more than $4 \mathrm{x}$ higher - than the price of diesel fuel on an equivalent energy basis. 


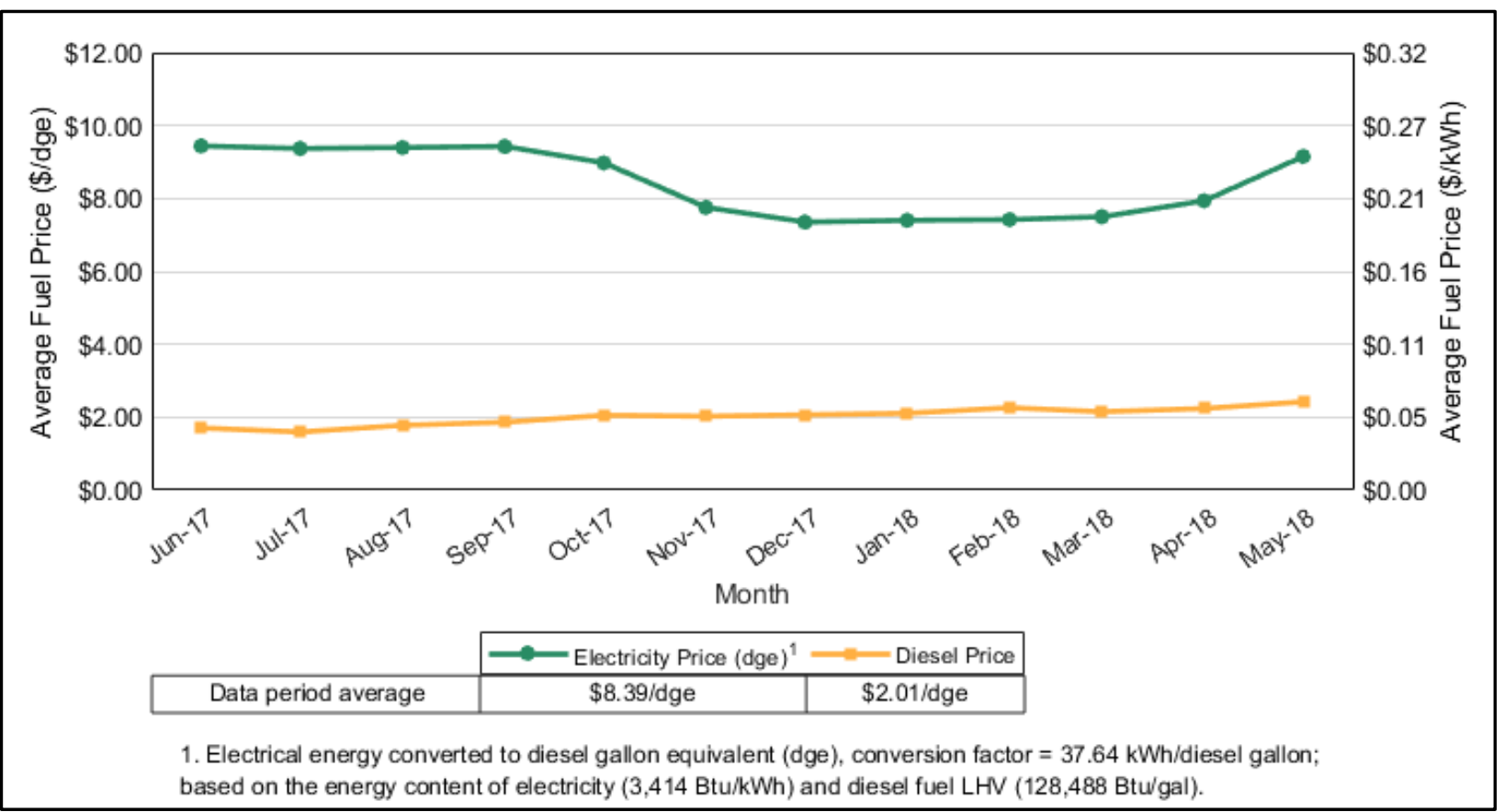

Figure 2-14. Monthly average fuel price for electricity and diesel fuel

The corresponding cost per mile of each fleet's fuel is compared in Figure 2-15. The per-mile fuel cost is a function of the unit price of the fuel (Figure 2-14) and the fuel efficiency of the buses (Figure 2-13).

The average fuel cost per mile for the battery fleet during the evaluation period was $\$ 0.73 / \mathrm{mi}$. The higher fuel economy of the battery buses during the cooler winter months combined with lower electricity prices during those months resulted in a much lower fuel cost per mile - around $\$ 0.60 / \mathrm{mi}$ - for November through April. Conversely, high electricity prices and lower fuel economy during the summer led to higher per-mile fuel costs, as high as \$0.99/mi in July 2017.

The per-mile fuel costs for the diesel buses were less sensitive to seasonal variations but showed a steady increase during the evaluation period, from a low of $\$ 0.32 / \mathrm{mi}$ in July 2017 to a high of $\$ 0.48 / \mathrm{mi}$ in May 2018. 


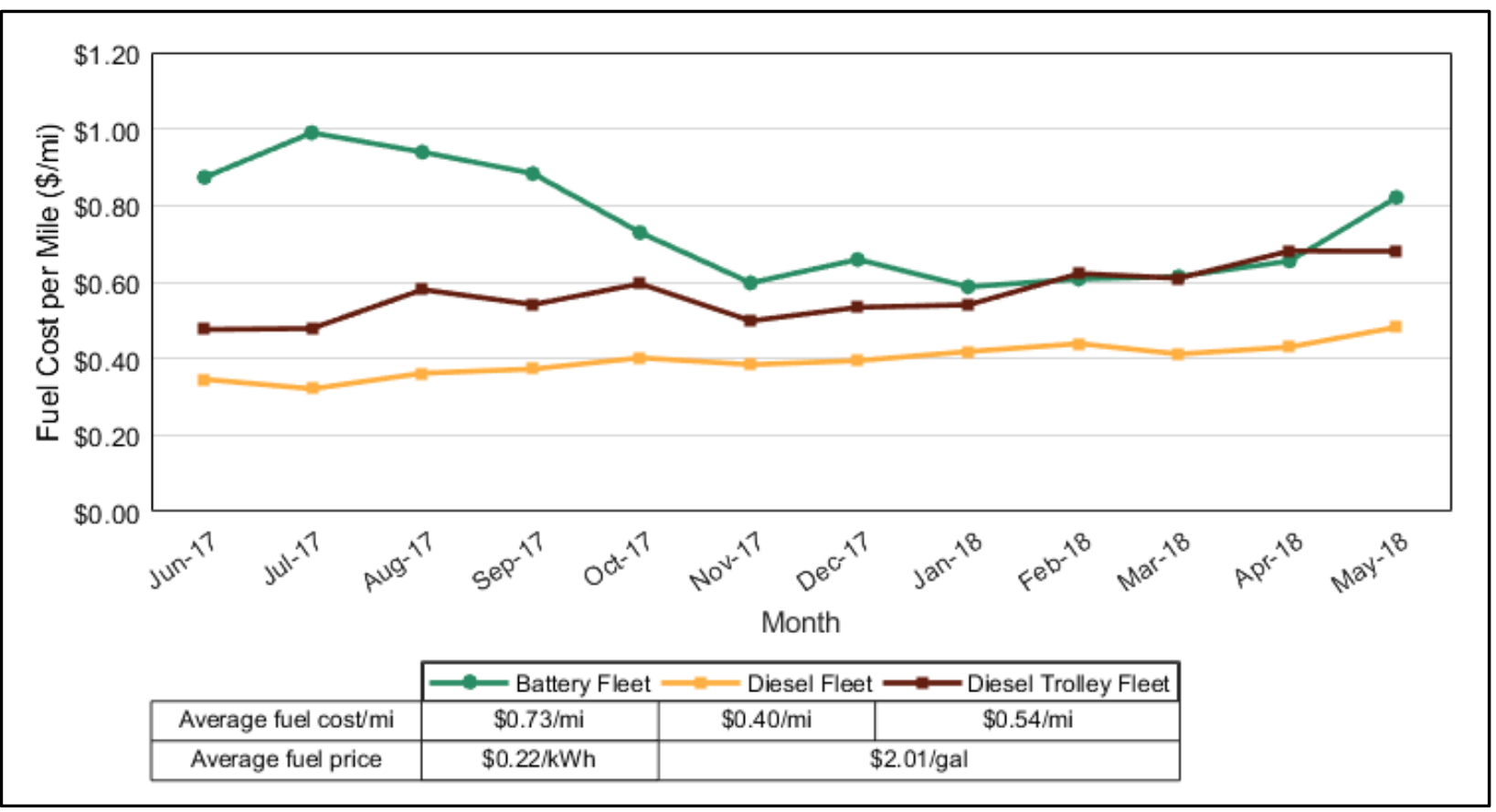

Figure 2-15. Monthly fuel cost per mile for the battery and diesel bus fleets

Figure 2-16 shows the overall monthly charging efficiency for the BEBs based on the total energy consumption of the fleet (recorded by the buses) and the total energy purchased for the charging stations (per the utility bills). These monthly totals are based on the utility billing periods and do not exactly match the calendar months. The efficiencies for each charging method are shown separately. The charging efficiency for the depot charging is $92.8 \%$ and the efficiency of the inductive charging is $85.2 \%$. The overall charging efficiency for the system averages to $86.9 \%$. 


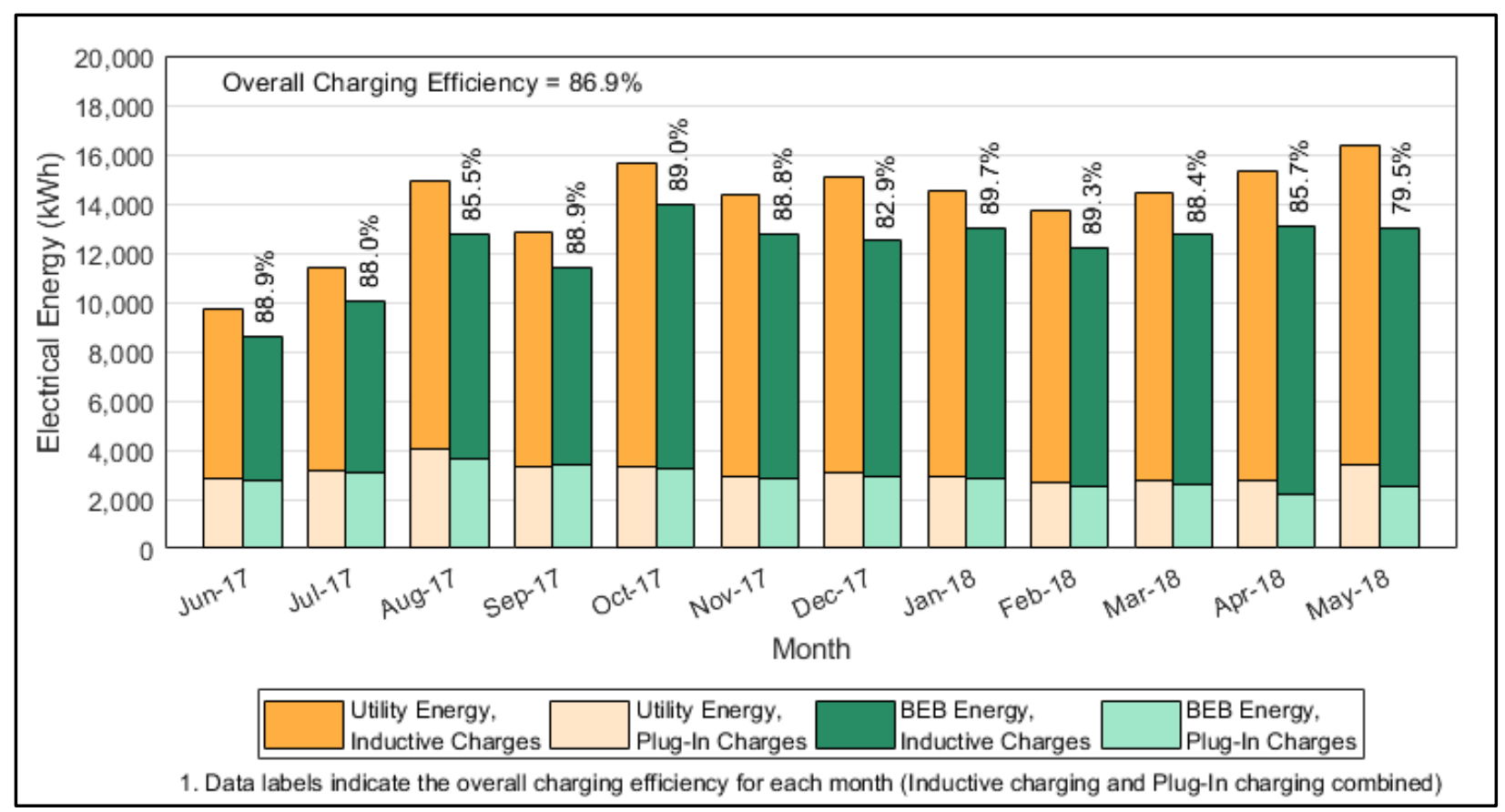

Figure 2-16. Monthly utility energy, bus energy, and charging efficiency

\subsubsection{Roadcall Analysis}

Table 2-7 provides the miles between roadcalls (MBRC) for the BEBs and diesel buses categorized by bus roadcalls, propulsion-related roadcalls, and ESS-related roadcalls. Figure 217 provides the cumulative MBRC for the battery buses and diesel baseline buses with total bus roadcalls on the upper chart and propulsion-related roadcalls and ESS-related roadcalls on the lower chart. Propulsion-related roadcalls are a subset of bus roadcalls for all bus fleets. ESSrelated roadcalls are a subset of the propulsion-related roadcalls, specific to the ESS of the battery buses. The DOE/FTA target for total bus MBRC of 4,000 is included in the graph as a red dashed line. The BEBs currently have a total bus MBRC of 4,686, which has surpassed the target.

Table 2-7. Roadcalls and MBRC

\begin{tabular}{|l|c|c|}
\hline & BEB & Diesel \\
\hline Dates & $6 / 17-5 / 18$ & $6 / 17-5 / 18$ \\
\hline Mileage & 51,550 & 189,068 \\
\hline Bus roadcalls & 11 & 3 \\
\hline Bus MBRC & 4,686 & 63,023 \\
\hline Propulsion-related roadcalls & 8 & 1 \\
\hline Propulsion-related MBRC & 6,444 & 189,068 \\
\hline ESS-related roadcalls & 3 & \\
\hline ESS-related MBRC & 17,183 & \\
\hline
\end{tabular}




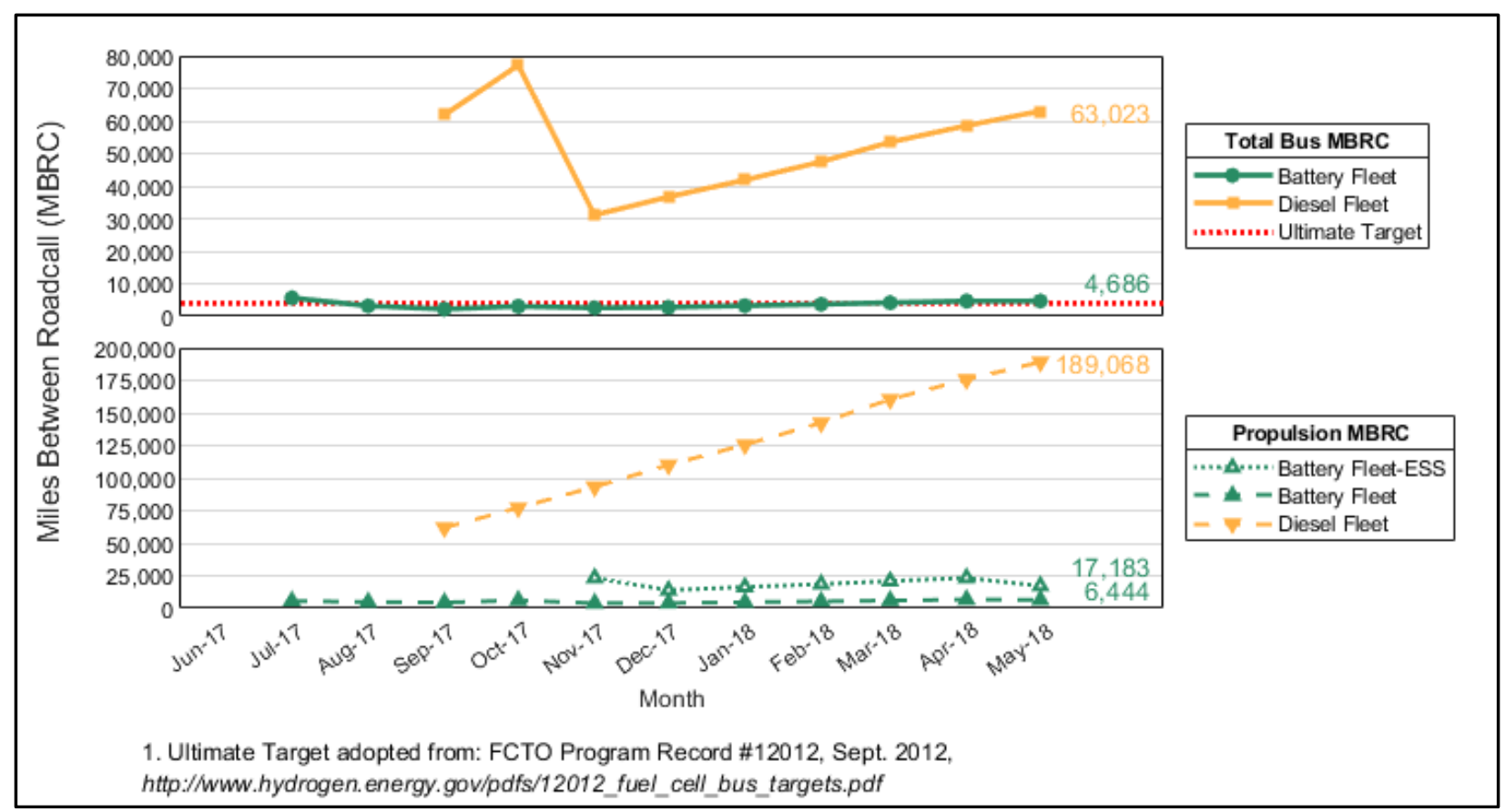

Figure 2-17. Cumulative bus MBRC and propulsion-related MBRC

\subsubsection{Maintenance Analysis}

This section first covers total maintenance costs and then maintenance costs by bus system. NREL excludes warranty repairs from the calculations. The battery buses were under warranty for the entire data period.

\subsubsection{Total Work Order Maintenance Costs}

Table 2-8 shows maintenance costs per mile for the bus fleets and includes total cost, scheduled cost, and unscheduled cost. Scheduled costs include PM based on the OEMs' recommendations. All other maintenance is included in unscheduled costs. The warranty work-which is not included in the analysis - was handled by the OEMs. During the data period, the maintenance cost for the battery buses was $13 \%$ less than that of the diesel buses. 
Table 2-8. Total Work Order Maintenance Costs

\begin{tabular}{|c|c|c|c|c|c|c|}
\hline Bus Fleet & Mileage & Parts (\$) & $\begin{array}{l}\text { Labor } \\
\text { Hours }\end{array}$ & $\begin{array}{l}\text { Scheduled } \\
\text { Cost per } \\
\text { Mile }(\$)\end{array}$ & $\begin{array}{c}\text { Unscheduled } \\
\text { Cost per Mile } \\
\text { (\$) }\end{array}$ & $\begin{array}{c}\text { Total Cost } \\
\text { per Mile } \\
\text { (\$) }\end{array}$ \\
\hline 1600 & 15,289 & 667.74 & 80.5 & 0.04 & 0.26 & 0.31 \\
\hline 1601 & 11,486 & $1,129.93$ & 87.5 & 0.06 & 0.42 & 0.48 \\
\hline 1602 & 11,697 & 762.86 & 97.0 & 0.12 & 0.36 & 0.48 \\
\hline 1603 & 13,079 & 530.92 & 72.5 & 0.09 & 0.23 & 0.32 \\
\hline Battery Total & 51,550 & $3,091.45$ & 337.5 & 0.08 & 0.31 & 0.39 \\
\hline 1400 & 23,152 & $2,799.79$ & 150.8 & 0.10 & 0.34 & 0.45 \\
\hline 1401 & 22,176 & $5,266.48$ & 169.8 & 0.09 & 0.53 & 0.62 \\
\hline 1402 & 27,834 & $2,595.40$ & 167.0 & 0.09 & 0.30 & 0.39 \\
\hline 1403 & 27,150 & $2,701.37$ & 141.0 & 0.10 & 0.26 & 0.36 \\
\hline 1404 & 29,269 & $3,949.23$ & 165.5 & 0.11 & 0.31 & 0.42 \\
\hline 1405 & 27,875 & $1,996.20$ & 145.8 & 0.09 & 0.25 & 0.33 \\
\hline 1406 & 31,612 & $9,346.49$ & 163.6 & 0.07 & 0.49 & 0.55 \\
\hline Diesel Total & 189,068 & $28,654.96$ & $1,103.3$ & 0.09 & 0.35 & 0.44 \\
\hline
\end{tabular}

The monthly scheduled and unscheduled maintenance cost per mile for both fleets of buses are shown as stacked columns in Figure 2-18. The high maintenance costs for the diesel buses during July 2017 were due to five buses reaching the mileage for a major PM and four buses experiencing issues with the exhaust system. The high cost in April 2018 was primarily for replacement of Intelligent Transportation System equipment on one bus. Issues with the battery management system and general bus issues increased the cost for the battery buses in November 2017. The higher battery bus costs in May 2018 were due to cooling system issues and general bus issues. 


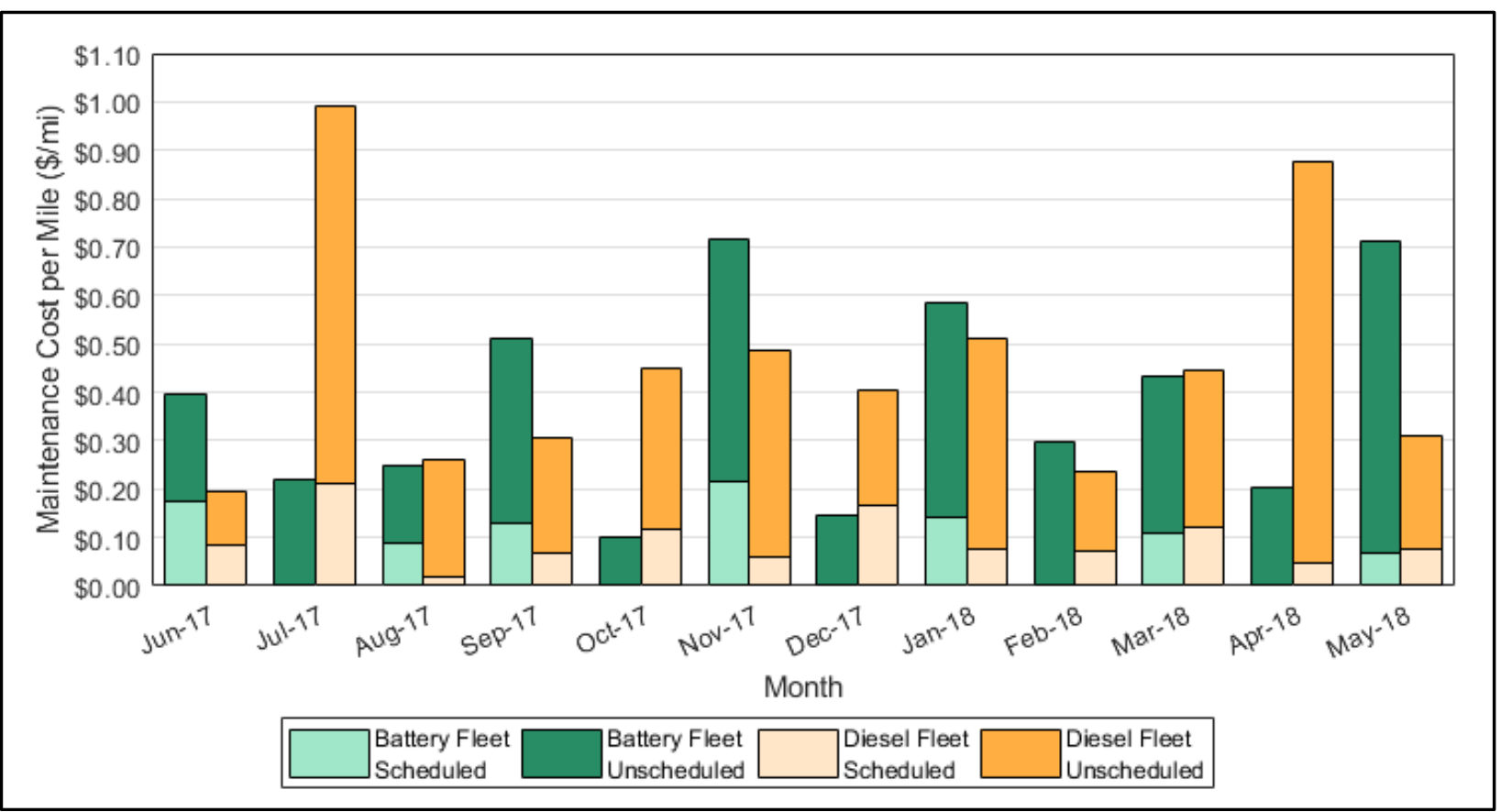

Figure 2-18. Monthly scheduled and unscheduled maintenance cost per mile for the battery and diesel fleets

\subsubsection{Work Order Maintenance Costs Categorized by System}

Table 2-9 shows maintenance costs per mile by vehicle system and bus fleet (without warranty costs). The vehicle systems shown in the table are as follows:

- Cab, body, and accessories: Includes body, glass, cab and sheet metal, seats and doors, and accessory repairs such as hubodometers and radios

- Propulsion-related systems: Repairs for exhaust, fuel, engine, electric motors, battery modules, propulsion control, non-lighting electrical (charging, cranking and ignition), air intake, cooling, and transmission

- PMI: Labor for inspections during preventive maintenance

- Brakes: Includes brake pads, disks, calipers, anti-lock braking system, and brake chambers

- Frame, steering, and suspension

- HVAC

- Lighting

- Air system (general)

- Axles, wheels, and drive shaft

- Tires. 
Table 2-9. Work Order Maintenance Cost per Mile by System ${ }^{a}$

\begin{tabular}{|l|c|c|c|c|}
\hline \multicolumn{1}{|c|}{ System } & $\begin{array}{c}\text { BEB System } \\
\text { Cost per } \\
\text { Mile (\$) }\end{array}$ & $\begin{array}{c}\text { BEB System } \\
\text { Percent of } \\
\text { Total (\%) }\end{array}$ & $\begin{array}{c}\text { Diesel } \\
\text { Cost per } \\
\text { Mile (\$) }\end{array}$ & $\begin{array}{c}\text { Diesel } \\
\text { Percent of } \\
\text { Total (\%) }\end{array}$ \\
\hline Propulsion-related & 0.10 & 25.7 & 0.14 & 31.1 \\
\hline Cab, body, and accessories & 0.14 & 36.4 & 0.16 & 35.3 \\
\hline PMI & 0.07 & 17.5 & 0.06 & 14.4 \\
\hline Brakes & 0.02 & 6.3 & 0.04 & 9.3 \\
\hline Frame, steering, and suspension & 0.01 & 3.6 & 0.01 & 2.1 \\
\hline HVAC & 0.01 & 1.9 & 0.02 & 3.9 \\
\hline Lighting & 0.02 & 4.5 & 0.00 & 1.0 \\
\hline General air system repairs & 0.00 & 0.7 & 0.01 & 1.5 \\
\hline Axles, wheels, and drive shaft & 0.00 & 0.0 & 0.01 & 1.2 \\
\hline Tires & 0.00 & 0.6 & 0.00 & 0.3 \\
\hline Inductive charging system & 0.01 & 2.8 & - & - \\
\hline Total & $\mathbf{0 . 3 9}$ & 100 & $\mathbf{0 . 4 4}$ & 100 \\
\hline
\end{tabular}

a The top three categories for maintenance for each fleet are color coded as follows: orange-highest, greensecond highest, and purple—-third highest.

The color shading denotes the systems with the highest percentage of maintenance costs: orange for the highest, green for the second highest, and purple for the third highest. The systems with the highest percentage of maintenance costs for the battery buses and diesel buses were the same: 1) cab, body, and accessories; 2) propulsion-related; and 3) PMI. Figure 2-19 shows the monthly cost per mile by system for the BEB system (battery bus fleet and inductive charger). Repairs included a coolant sensor, replacement of low-voltage batteries, electrical system, and issues with the battery management for the energy storage system. 


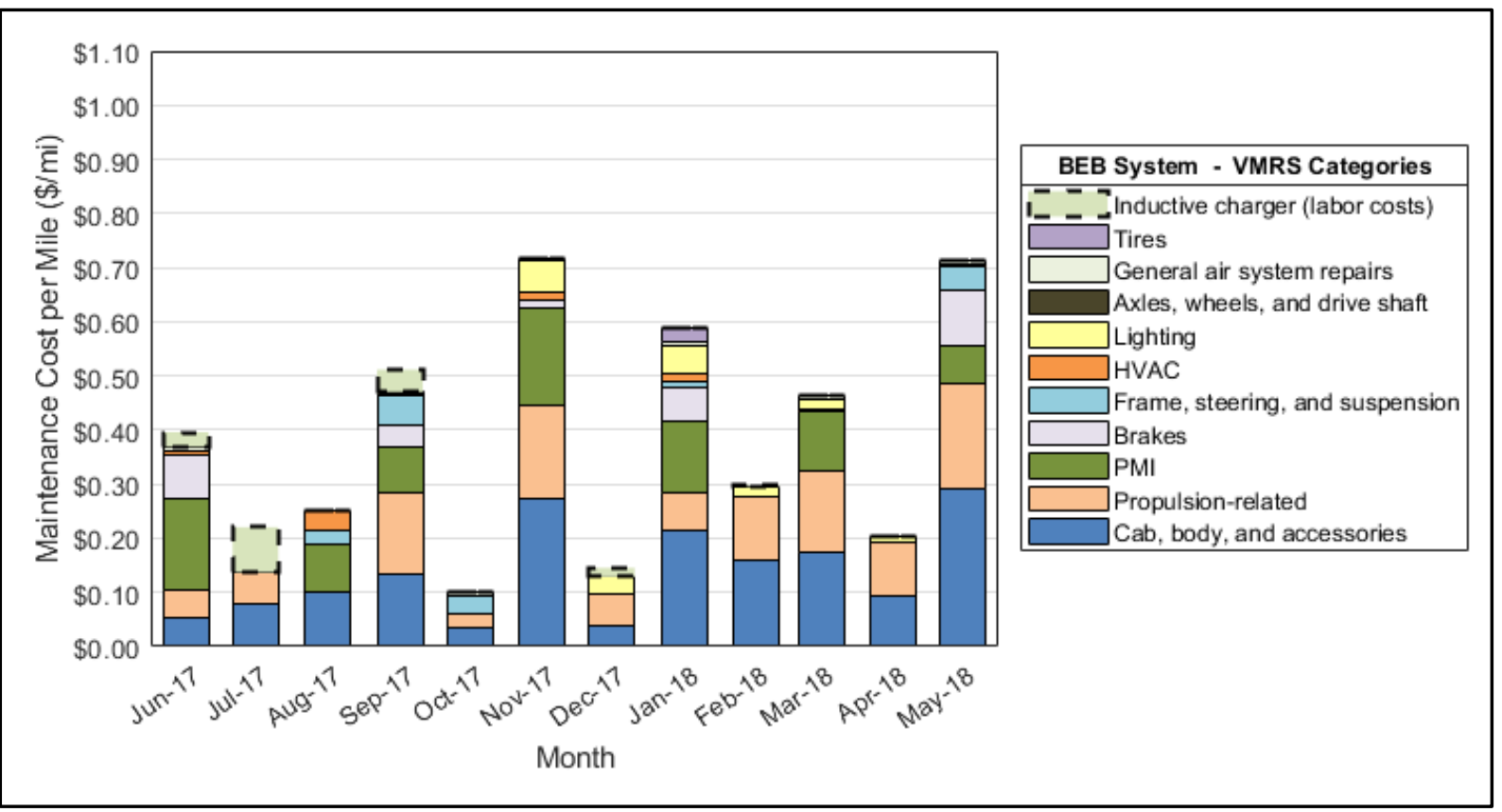

Figure 2-19. Monthly maintenance cost per mile by system for the BEB system (battery bus fleet and inductive charger)

Figure 2-20 shows the monthly cost per mile by system for the diesel fleet. The majority of issues with the diesel buses were in the cab, body, and accessories category. Issues included problems with mirrors, glass, and seats. Propulsion category issues included problems with turbochargers, exhaust system, electrical system, and low-voltage batteries.

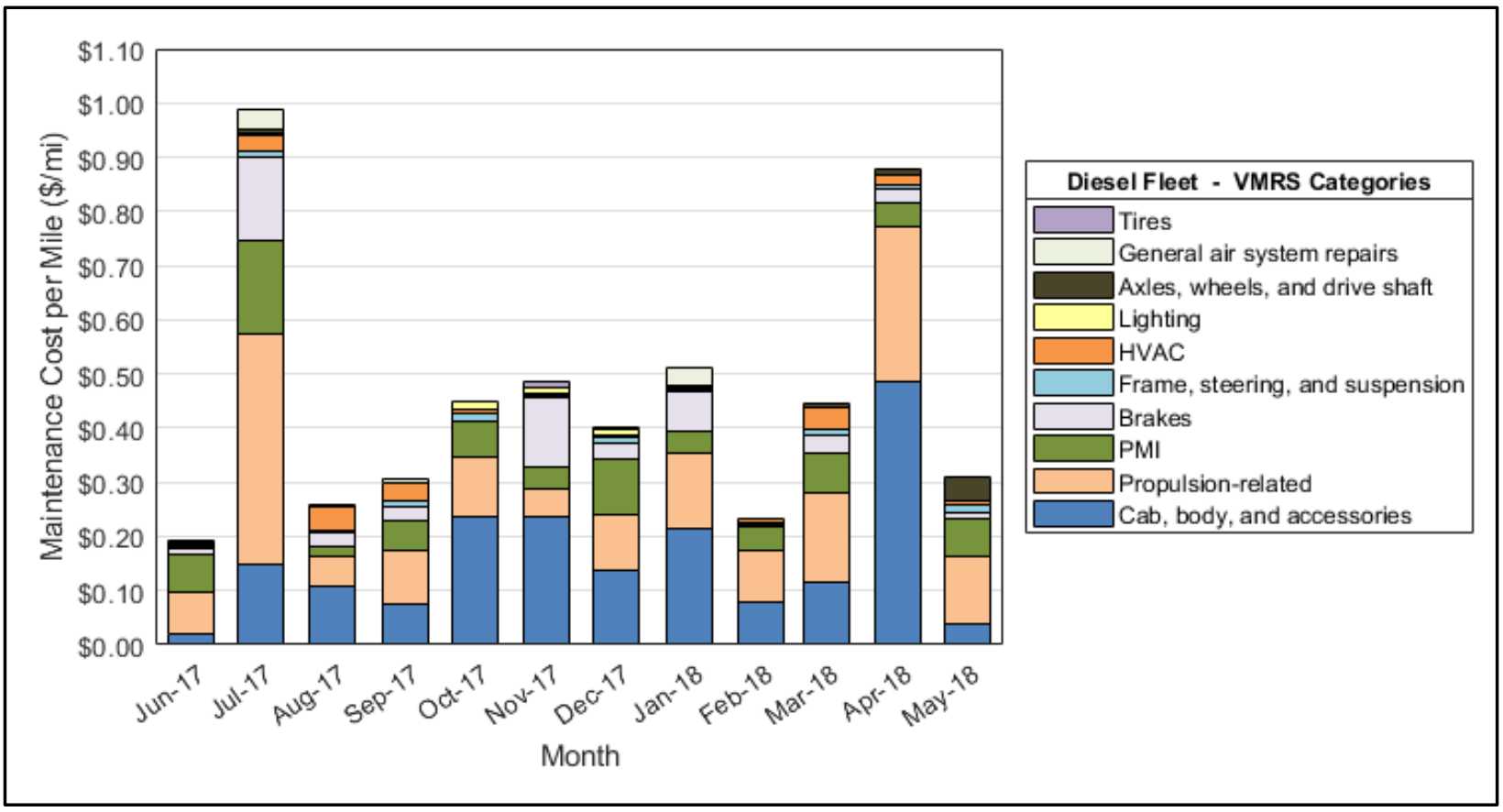

Figure 2-20. Monthly maintenance cost per mile by system for the diesel bus fleet 


\subsubsection{Propulsion-Related Work Order Maintenance Costs}

Propulsion-related vehicle systems include the exhaust, fuel, engine, battery modules, electric propulsion, air intake, cooling, non-lighting electrical, transmission, and hydraulic systems. These vehicle subsystems have been separated to highlight how maintenance costs for the propulsion system are affected by the change from conventional technology (diesel) to advanced technology (batteries). Table 2-10 shows the propulsion-related system maintenance costs by category for the two fleets during the data period. Parts for scheduled maintenance, such as filters and fluids, are included in the specific system categories. For example, oil and oil filters are included in the power plant (engine) subsystem parts costs, while air filters are included in the air intake subsystem parts costs.

- Total propulsion-related-The battery fleet's total propulsion-related maintenance cost was $28 \%$ lower than that of the diesel buses.

- Exhaust system - Costs for the diesel buses were low. The battery buses do not have exhaust systems.

- Fuel system - Costs for this system for the diesel buses were low. The battery buses do not have a liquid fueling system.

- Power plant and electric propulsion-For the battery buses, the electric propulsion system accounted for $45 \%$ of the total propulsion system costs. Power plant (engine) repairs made up $31 \%$ of the total propulsion system costs for the diesel buses.

- Non-lighting electrical (charging, cranking, and ignition) - Costs for this system for the battery buses were $80 \%$ higher than for the diesel buses due to the cost for replacing low-voltage batteries.

- Air intake - Costs for this system for the battery and diesel buses were low.

- Cooling - Costs for this system for the battery buses were low. For the diesel buses, cooling system repairs made up $17 \%$ of the propulsion system costs.

- Transmission - Costs for this system were low for the diesel buses. The BEBs do not have a transmission.

- Hydraulic - Costs for this system were zero for both bus fleets. 
Table 2-10. Propulsion-Related Work Order Maintenance Costs by System

\begin{tabular}{|c|c|c|c|}
\hline Maintenance System & Maintenance Costs & BEB & Diesel \\
\hline Mileage & & 51,550 & 189,068 \\
\hline \multirow{4}{*}{$\begin{array}{l}\text { Total Propulsion-Related } \\
\text { Systems } \\
\text { (Roll-up) }\end{array}$} & Parts cost (\$) & $1,515.75$ & $12,065.48$ \\
\hline & Labor hours & 72.3 & 279.5 \\
\hline & Total cost $(\$)$ & $5,128.25$ & $26,040.48$ \\
\hline & Total cost (\$) per mile & 0.099 & 0.138 \\
\hline \multirow{4}{*}{ Exhaust System Repairs } & Parts cost (\$) & 0.00 & $3,670.13$ \\
\hline & Labor hours & 0.0 & 50.0 \\
\hline & Total cost $(\$)$ & 0.00 & $6,170.13$ \\
\hline & Total cost $(\$)$ per mile & 0.000 & 0.033 \\
\hline \multirow{4}{*}{ Fuel System Repairs } & Parts cost $(\$)$ & 0.00 & 435.60 \\
\hline & Labor hours & 0.0 & 9.0 \\
\hline & Total cost $(\$)$ & 0.00 & 885.60 \\
\hline & Total cost (\$) per mile & 0.000 & 0.005 \\
\hline \multirow{4}{*}{$\begin{array}{l}\text { Powerplant System } \\
\text { Repairs (Energy Storage } \\
\text { System for BEBs) }\end{array}$} & Parts cost (\$) & 4.78 & $3,300.52$ \\
\hline & Labor hours & 27.8 & 96.3 \\
\hline & Total cost $(\$)$ & $1,392.28$ & $8,113.02$ \\
\hline & Total cost (\$) per mile & 0.027 & 0.043 \\
\hline \multirow{4}{*}{$\begin{array}{l}\text { Electric Propulsion } \\
\text { System Repairs }\end{array}$} & Parts cost $(\$)$ & 467.47 & 0.00 \\
\hline & Labor hours & 37.3 & 0.0 \\
\hline & Total cost $(\$)$ & $2,329.97$ & 0.00 \\
\hline & Total cost (\$) per mile & 0.045 & 0.000 \\
\hline \multirow{4}{*}{$\begin{array}{l}\text { Non-Lighting Electrical } \\
\text { System Repairs (General } \\
\text { Electrical, Charging, } \\
\text { Cranking, Ignition) }\end{array}$} & Parts cost $(\$)$ & $1,043.50$ & $1,587.46$ \\
\hline & Labor hours & 5.0 & 21.0 \\
\hline & Total cost $(\$)$ & $1,293.50$ & $2,637.46$ \\
\hline & Total cost (\$) per mile & 0.025 & 0.014 \\
\hline \multirow{4}{*}{ Air Intake System Repairs } & Parts cost $(\$)$ & 0.00 & $1,332.14$ \\
\hline & Labor hours & 0.3 & 8.8 \\
\hline & Total cost $(\$)$ & 12.50 & $1,769.64$ \\
\hline & Total cost (\$) per mile & 0.000 & 0.009 \\
\hline \multirow{4}{*}{ Cooling System Repairs } & Parts cost (\$) & 0.00 & 586.97 \\
\hline & Labor hours & 2.0 & 75.5 \\
\hline & Total cost $(\$)$ & 100.00 & $4,361.97$ \\
\hline & Total cost (\$) per mile & 0.002 & 0.023 \\
\hline \multirow{4}{*}{$\begin{array}{l}\text { Transmission System } \\
\text { Repairs }\end{array}$} & Parts cost $(\$)$ & 0.00 & $1,152.66$ \\
\hline & Labor hours & 0.0 & 19.0 \\
\hline & Total cost $(\$)$ & 0.00 & $2,102.66$ \\
\hline & Total cost (\$) per mile & 0.000 & 0.011 \\
\hline \multirow{4}{*}{ Hydraulic System Repairs } & Parts cost $(\$)$ & 0.00 & 0.00 \\
\hline & Labor hours & 0.0 & 0.0 \\
\hline & Total cost $(\$)$ & 0.00 & 0.00 \\
\hline & Total cost (\$) per mile & 0.000 & 0.000 \\
\hline
\end{tabular}




\subsubsection{Total Cost}

Figure 2-21 shows the monthly total operational cost per mile, including maintenance and fuel cost, for the battery and diesel fleets. Energy costs dominate the battery fleet's overall operational costs and are higher during the summer months when the electric rate increases. Diesel fuel costs are consistent over the data period. Table 2-11 summarizes the overall fuel and maintenance costs per mile by bus fleet. These parameters are also listed in Appendix A.

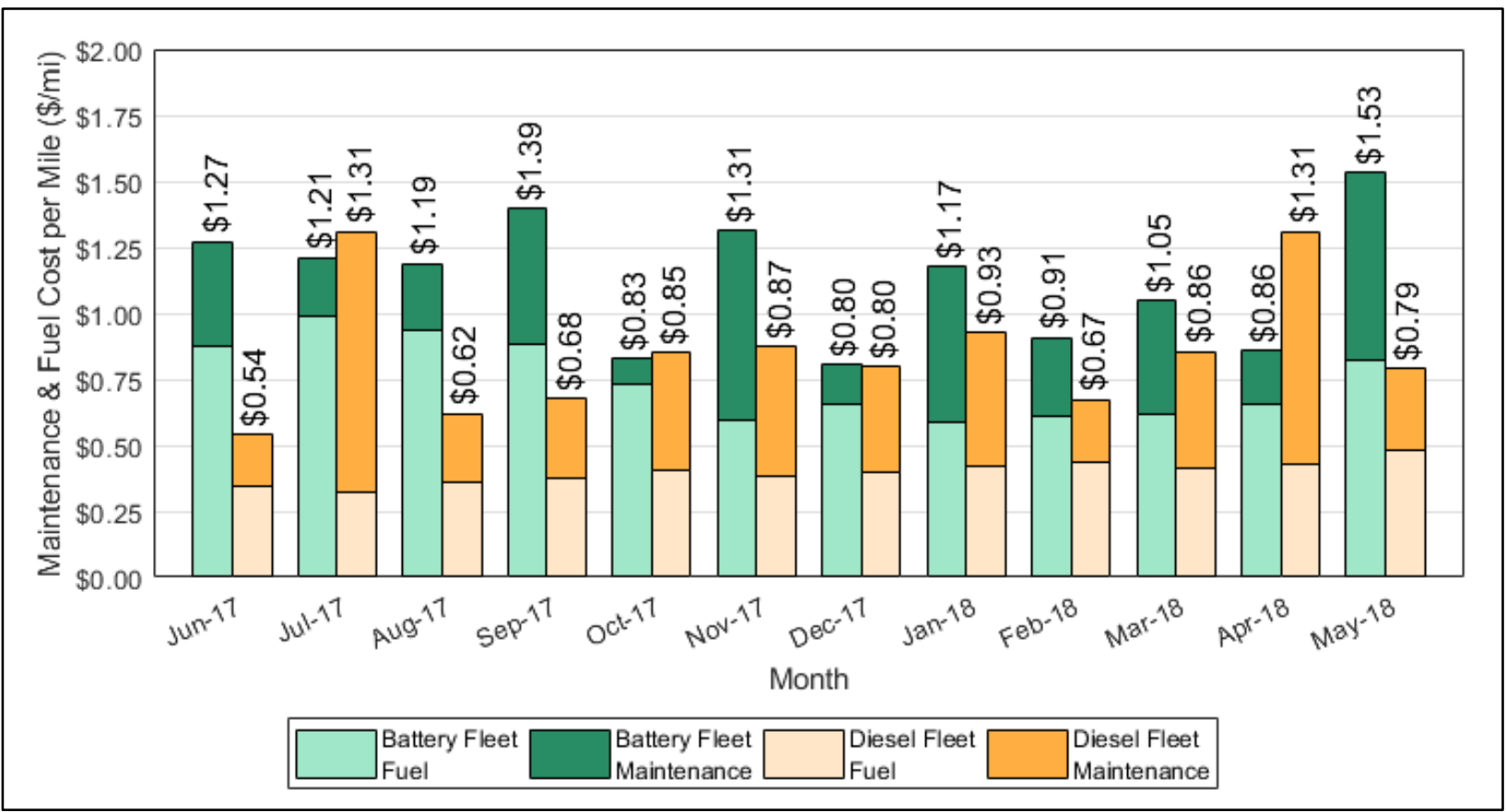

Figure 2-21. Monthly operations (maintenance and fuel) cost for the battery and diesel bus fleets

Table 2-11. Overall Operations (Maintenance and Fuel) Cost per Mile

\begin{tabular}{|l|r|r|}
\hline & Battery & Diesel \\
\hline Fuel cost per mile $(\$ / \mathrm{mi})$ & 0.73 & 0.40 \\
\hline Total maintenance cost per mile $(\$ / \mathrm{mi})$ & 0.39 & 0.44 \\
\hline Total operating cost per mile $\mathbf{( \$ / \mathrm { mi } )}$ & $\mathbf{1 . 1 1}$ & $\mathbf{0 . 8 4}$ \\
\hline
\end{tabular}

\subsection{Summary of Achievements and Challenges}

As with all new technology development, lessons learned during this project could aid other agencies considering BEB technology. The team reports a number of successes that include the following:

- Implemented the agency's first BEB fleet

- Fully electrified the Walnut Creek route

- Accumulated more than 51,500 miles on the battery buses in the first year of revenue service. 


\subsubsection{Summary of Challenges}

Advanced-technology demonstrations typically experience challenges and issues that need to be resolved. Issues and lessons learned for County Connection include the following.

Charger availability - When deploying a BEB fleet, availability of an on-route charger is critical for operation. Downtime of a charger results in downtime for the fleet. Early in this evaluation, County Connection experienced a couple issues with the inductive charger that decreased the battery fleet availability. Importantly, none of the issues were related to the electrical circuitry or wireless charging components; rather, the issues were related to ancillary cooling equipment. The primary issue, responsible for the June/July 2017 downtime, was a failure of the chiller's compressor. Subsequent investigation of the component by the manufacturer indicates that a power surge from a lightning strike occurred, requiring the compressor to be replaced. In October 2017, a slow leak in an external coolant line led to a shutdown of the cooling system. The coolant line was replaced with a more durable material.

Charger efficiency - During investigation of the inductive charger performance, WAVE provided additional information about the design of the charger's cooling system which had an impact on the overall efficiency. The cooling system for this particular installation of the $50-\mathrm{kW}$ charger was intentionally oversized to allow for up to $100 \%$ duty cycle charging in a hot environment because system uptime and meeting transit service requirements were the highest priorities for County Connection. There were also conservative settings for pre- and post-cooling of the water tank to ensure reliability, rather than efficiency, of the system. WAVE reported that major improvements have been made to the cooling system design of the inductive charger since this first-generation product, improving the efficiency of their higher power charger to $92 \%$ (typical) and avoiding issues experienced in the early months of this deployment.

Added operating costs - When adding BEBs with depot charging to a fleet, an agency needs to plan for logistics to plug in and move the buses to and from the charger at the depot. This is especially true for fleets that don't install a charger for each bus. County Connection reports that this adds labor costs to the project. Because the agency has two chargers to cover the fleet of four buses, staff are needed to stage and move the buses to ensure each one gets fully charged before parking overnight. Scaling up to a larger fleet will add complexity to this process. For BEBs with on-route charging, additional time may need to be planned into the route schedule. County Connection has added a half hour to the beginning and end of each operator shift to allow time for the BEBs to charge at the inductive charger prior to starting the route and before returning to the depot. This adds to the labor needs for operating BEBs. Some agencies may only experience one of these two impacts, but County Connection is operating both types of chargers and has decided to top off the charge of the buses on route and at the depot.

Maintenance costs - Because the BEBs are under warranty, some repairs were made that are not accounted for in the maintenance records. Labor and parts costs for repairs that are handled by the OEM are not typically included in maintenance data sets and NREL is unable to analyze and report on them. At this point in the demonstration, post-warranty maintenance costs are unknown. Agencies should carefully consider this when using early reported costs to plan for BEB fleet implementation and long-term maintenance costs. 
Maintenance skill set-Deploying new technologies presents a challenge for transit staff to take over all maintenance responsibilities after the warranty period ends. Current staff do not have the skill set needed to fully maintain BEBs. Additional labor hours are incurred as staff come up to speed on the new technology. In addition, there is a shortage in the hiring pool of technicians with the desired skill sets. The industry is addressing this need by working with community colleges and technical schools to add the required courses for ZEB technicians. The updated training materials are still in the beginning stages of development, therefore current graduates do not yet have the needed skill set. Until these programs are fully established, hiring ZEB qualified technicians will be a challenge. 


\section{County Connection Fleet Summary Statistics}

Table 3-1. County Connection-Fleet Operations and Economics

\begin{tabular}{|l|r|r|}
\hline & \multicolumn{1}{|c|}{ BEB } & \multicolumn{1}{c|}{ Diesel } \\
\hline Number of vehicles & 4 & 8 \\
\hline Period used for fuel and energy op analysis & $6 / 17-5 / 18$ & $6 / 17-5 / 18$ \\
\hline Total number of months in period & 12 & 12 \\
\hline Fuel and energy analysis base fleet mileage & 51,550 & 189,068 \\
\hline Period used for maintenance op analysis & $6 / 17-5 / 18$ & $6 / 17-5 / 18$ \\
\hline Total number of months in period & 12 & 12 \\
\hline Maintenance analysis base fleet mileage & 51,550 & 189,068 \\
\hline Average monthly mileage per vehicle & 1,074 & 1,969 \\
\hline Availability & 77 & 86 \\
\hline Fleet energy usage in kWh for BEB / gal for diesel & $46,152.3$ & $37,146.0$ \\
\hline Purchased electrical energy in kWh for BEB & $68,274.3$ & - \\
\hline Roadcalls & 11 & 3 \\
\hline Total MBRC & 4,686 & 63,023 \\
\hline Propulsion roadcalls & 8 & 1 \\
\hline Propulsion MBRC & 6,444 & 189,068 \\
\hline Fleet kWh/mile & 2.84 & 7.40 \\
\hline Representative fleet mpg (diesel energy equivalent) & 13.28 & 5.09 \\
\hline Energy cost per kWh / diesel cost per gal & 0.22 & 2.02 \\
\hline Energy/fuel cost per mile (based on purchased energy) & 0.73 & 0.40 \\
\hline Total scheduled repair cost per mile & 0.08 & 0.09 \\
\hline Total unscheduled repair cost per mile & 0.31 & 0.35 \\
\hline Total maintenance cost per mile & 0.39 & 0.44 \\
\hline Total operating cost per mile & $\mathbf{1 . 1 1}$ & $\mathbf{0 . 8 4}$ \\
\hline
\end{tabular}

Table 3-2. County Connection-Maintenance Costs

\begin{tabular}{|l|r|r|}
\hline & \multicolumn{1}{|c|}{ BEB } & \multicolumn{1}{c|}{ Diesel } \\
\hline Fleet mileage & 51,550 & 189,068 \\
\hline Total parts cost $(\$)$ & $3,091.45$ & $28,654.96$ \\
\hline Total labor hours & 337.5 & $1,103.3$ \\
\hline Total labor cost $@ \$ 50.00$ per hour) $(\$)$ & $16,872.50$ & $55,165.00$ \\
\hline Total maintenance cost $(\$)$ & $19,963.95$ & $83,819.96$ \\
\hline Total maintenance cost per bus (\$) & $4,990.99$ & $11,974.28$ \\
\hline Total maintenance cost per $\mathbf{m i l e ~ ( \$ / m i )}$ & $\mathbf{0 . 3 9}$ & $\mathbf{0 . 4 4}$ \\
\hline
\end{tabular}


Table 3-3. County Connection-Breakdown of Maintenance Costs by System

\begin{tabular}{|c|c|c|}
\hline & BEB & Diesel \\
\hline Fleet mileage & 51,550 & 189,068 \\
\hline \multicolumn{3}{|c|}{$\begin{array}{l}\text { Total Engine/Fuel-Related Systems (ATA VMRS 27, 30, 31, 32, 33, 41, 42, 43, 44, 45, } \\
46,65 \text { ) }\end{array}$} \\
\hline Parts cost & $1,515.75$ & $12,065.48$ \\
\hline Labor hours & 72.25 & 279.50 \\
\hline Average labor cost & $3,612.50$ & $13,975.00$ \\
\hline Total cost (for system) & $5,128.25$ & $26,040.48$ \\
\hline Total cost (for system) per bus & $1,282.06$ & $6,510.12$ \\
\hline Total cost (for system) per mile & 0.10 & 0.14 \\
\hline \multicolumn{3}{|c|}{ Exhaust System Repairs (ATA VMRS 43) } \\
\hline Parts cost & 0.00 & $3,670.13$ \\
\hline Labor hours & 0.00 & 50.0 \\
\hline Average labor cost & 0.00 & $2,500.00$ \\
\hline Total cost (for system) & 0.00 & $6,170.13$ \\
\hline Total cost (for system) per bus & 0.00 & $1,542.53$ \\
\hline Total cost (for system) per mile & 0.00 & 0.03 \\
\hline \multicolumn{3}{|c|}{ Fuel System Repairs (ATA VMRS 44) } \\
\hline Parts cost & 0.00 & 435.60 \\
\hline Labor hours & 0.0 & 9.0 \\
\hline Average labor cost & 0.00 & 450.00 \\
\hline Total cost (for system) & 0.00 & 885.60 \\
\hline Total cost (for system) per bus & 0.00 & 221.40 \\
\hline Total cost (for system) per mile & 0.00 & 0.00 \\
\hline \multicolumn{3}{|c|}{ Power Plant (Engine or ESS) Repairs (ATA VMRS 45) } \\
\hline Parts cost & 4.78 & $3,300.52$ \\
\hline Labor hours & 27.8 & 96.3 \\
\hline Average labor cost & $1,387.50$ & $4,812.50$ \\
\hline Total cost (for system) & $1,392.28$ & $8,113.02$ \\
\hline Total cost (for system) per bus & 348.07 & $2,028.26$ \\
\hline Total cost (for system) per mile & 0.03 & 0.04 \\
\hline \multicolumn{3}{|c|}{ Electric Propulsion Repairs (ATA VMRS 46) } \\
\hline Parts cost & 467.47 & 0.00 \\
\hline Labor hours & 37.3 & 0.0 \\
\hline Average labor cost & $1,862.50$ & 0.00 \\
\hline Total cost (for system) & $2,329.97$ & 0.00 \\
\hline Total cost (for system) per bus & 582.49 & 0.00 \\
\hline Total cost (for system) per mile & 0.05 & 0.00 \\
\hline
\end{tabular}


Table 3-3. County Connection-Breakdown of Maintenance Costs by System (continued)

\begin{tabular}{|c|c|c|}
\hline & BEB & Diesel \\
\hline \multicolumn{3}{|c|}{$\begin{array}{l}\text { Electrical System Repairs (ATA VMRS 30-Electrical General, 31-Charging, 32- } \\
\text { Cranking, 33-Ignition) }\end{array}$} \\
\hline Parts cost & $1,043.50$ & $1,587.46$ \\
\hline Labor hours & 5.0 & 21.0 \\
\hline Average labor cost & 250.00 & $1,050.00$ \\
\hline Total cost (for system) & $1,293.50$ & $2,637.46$ \\
\hline Total cost (for system) per bus & 323.38 & 659.37 \\
\hline Total cost (for system) per mile & 0.03 & 0.01 \\
\hline \multicolumn{3}{|c|}{ Air Intake System Repairs (ATA VMRS 41) } \\
\hline Parts cost & 0.00 & $1,332.14$ \\
\hline Labor hours & 0.3 & 8.8 \\
\hline Average labor cost & 12.50 & 437.50 \\
\hline Total cost (for system) & 12.50 & $1,769.64$ \\
\hline Total cost (for system) per bus & 3.13 & 442.41 \\
\hline Total cost (for system) per mile & 0.00 & 0.01 \\
\hline \multicolumn{3}{|c|}{ Cooling System Repairs (ATA VMRS 42) } \\
\hline Parts cost & 0.00 & 586.97 \\
\hline Labor hours & 2.0 & 75.5 \\
\hline Average labor cost & 100.00 & $3,775.00$ \\
\hline Total cost (for system) & 100.00 & $4,361.97$ \\
\hline Total cost (for system) per bus & 25.00 & $1,090.49$ \\
\hline Total cost (for system) per mile & 0.00 & 0.02 \\
\hline \multicolumn{3}{|c|}{ Hydraulic System Repairs (ATA VMRS 65) } \\
\hline Parts cost & 0.00 & 0.0 \\
\hline Labor hours & 0.0 & 0.0 \\
\hline Average labor cost & 0.00 & 0.00 \\
\hline Total cost (for system) & 0.00 & 0.00 \\
\hline Total cost (for system) per bus & 0.00 & 0.00 \\
\hline Total cost (for system) per mile & 0.00 & 0.00 \\
\hline \multicolumn{3}{|c|}{ General Air System Repairs (ATA VMRS 10) } \\
\hline Parts cost & 41.95 & 239.24 \\
\hline Labor hours & 2.0 & 19.8 \\
\hline Average labor cost & 100.00 & 987.50 \\
\hline Total cost (for system) & 141.95 & $1,226.74$ \\
\hline Total cost (for system) per bus & 35.49 & 306.69 \\
\hline Total cost (for system) per mile & 0.00 & 0.01 \\
\hline
\end{tabular}


Table 3-3. County Connection-Breakdown of Maintenance Costs by System (continued)

\begin{tabular}{|c|c|c|}
\hline & BEB & Diesel \\
\hline \multicolumn{3}{|c|}{ Brake System Repairs (ATA VMRS 13) } \\
\hline Parts cost & 0.00 & 643.57 \\
\hline Labor hours & 25.0 & 143.0 \\
\hline Average labor cost & $1,250.00$ & $7,150.00$ \\
\hline Total cost (for system) & $1,250.00$ & $7,793.57$ \\
\hline Total cost (for system) per bus & 312.50 & $1,948.39$ \\
\hline Total cost (for system) per mile & 0.02 & 0.04 \\
\hline \multicolumn{3}{|c|}{ Transmission Repairs (ATA VMRS 27) } \\
\hline Parts cost & 0.00 & $1,152.66$ \\
\hline Labor hours & 0.0 & 19.0 \\
\hline Average labor cost & 0.00 & 950.00 \\
\hline Total cost (for system) & 0.00 & $2,102.66$ \\
\hline Total cost (for system) per bus & 0.00 & 525.67 \\
\hline Total cost (for system) per mile & 0.00 & 0.01 \\
\hline \multicolumn{3}{|c|}{ Inspections Only-No Parts Replacements (101) } \\
\hline Parts cost & 0.00 & 0.00 \\
\hline Labor hours & 69.8 & 242.0 \\
\hline Average labor cost & $3,487.50$ & $12,100.00$ \\
\hline Total cost (for system) & $3,487.50$ & $12,100.00$ \\
\hline Total cost (for system) per bus & 871.88 & $3,025.00$ \\
\hline Total cost (for system) per mile & 0.07 & 0.06 \\
\hline \multicolumn{3}{|c|}{$\begin{array}{l}\text { Cab, Body, and Accessories Systems Repairs (ATA VMRS 02-Cab and Sheet Metal, } \\
\text { 50-Accessories, 71-Body) }\end{array}$} \\
\hline Parts cost & 826.60 & $12,998.93$ \\
\hline Labor hours & 129.0 & 335.0 \\
\hline Average labor cost & $6,447.50$ & $16,750.00$ \\
\hline Total cost (for system) & $7,274.10$ & $29,748.93$ \\
\hline Total cost (for system) per bus & $1,818.53$ & $7,437.23$ \\
\hline Total cost (for system) per mile & 0.14 & 0.16 \\
\hline \multicolumn{3}{|c|}{ HVAC System Repairs (ATA VMRS 01) } \\
\hline Parts cost & 207.68 & $1,091.24$ \\
\hline Labor hours & 3.5 & 43.8 \\
\hline Average labor cost & 175.00 & $2,190.00$ \\
\hline Total cost (for system) & 382.68 & $3,281.24$ \\
\hline Total cost (for system) per bus & 95.67 & 820.31 \\
\hline Total cost (for system) per mile & 0.01 & 0.02 \\
\hline
\end{tabular}


Table 3-3. County Connection-Breakdown of Maintenance Costs by System (continued)

\begin{tabular}{|c|c|c|}
\hline & BEB & Diesel \\
\hline \multicolumn{3}{|c|}{ Lighting System Repairs (ATA VMRS 34) } \\
\hline Parts cost & 499.47 & 237.84 \\
\hline Labor hours & 8.0 & 11.3 \\
\hline Average labor cost & 400.00 & 562.50 \\
\hline Total cost (for system) & 899.47 & 800.34 \\
\hline Total cost (for system) per bus & 224.87 & 200.09 \\
\hline Total cost (for system) per mile & 0.02 & 0.00 \\
\hline \multicolumn{3}{|c|}{$\begin{array}{l}\text { Frame, Steering, and Suspension Repairs (ATA VMRS 14-Frame, 15-Steering, 16- } \\
\text { Suspension) }\end{array}$} \\
\hline Parts cost & 0.00 & 924.13 \\
\hline Labor hours & 14.5 & 16.3 \\
\hline Average labor cost & 725.00 & 812.50 \\
\hline Total cost (for system) & 725.00 & $1,736.63$ \\
\hline Total cost (for system) per bus & 181.25 & 434.16 \\
\hline Total cost (for system) per mile & 0.01 & 0.01 \\
\hline \multicolumn{3}{|c|}{$\begin{array}{l}\text { Axle, Wheel, and Drive Shaft Repairs (ATA VMRS 11-Front Axle, 18-Wheels, 22- } \\
\text { Rear Axle, 24-Drive Shaft) }\end{array}$} \\
\hline Parts cost & 0.00 & 591.53 \\
\hline Labor hours & 0.0 & 8.5 \\
\hline Average labor cost & 0.00 & 425.00 \\
\hline Total cost (for system) & 0.00 & $1,016.53$ \\
\hline Total cost (for system) per bus & 0.00 & 254.13 \\
\hline Total cost (for system) per mile & 0.00 & 0.01 \\
\hline \multicolumn{3}{|l|}{ Tire Repairs (ATA VMRS 17) } \\
\hline Parts cost & 0.00 & 0.00 \\
\hline Labor hours & 2.5 & 4.3 \\
\hline Average labor cost & 125.00 & 212.50 \\
\hline Total cost (for system) & 125.00 & 212.50 \\
\hline Total cost (for system) per bus & 31.25 & 53.13 \\
\hline Total cost (for system) per mile & 0.00 & 0.00 \\
\hline \multicolumn{3}{|l|}{ Inductive Charging System } \\
\hline Parts cost & 0.00 & 0.00 \\
\hline Labor hours & 11.0 & 0.0 \\
\hline Average labor cost & 550.00 & 0.00 \\
\hline Total cost (for system) & 550.00 & 0.00 \\
\hline Total cost (for system) per bus & 137.50 & 0.00 \\
\hline Total cost (for system) per mile & 0.01 & 0.00 \\
\hline
\end{tabular}




\subsection{Fleet Summary Statistics_-SI Units}

Table 3-4. County Connection-Fleet Operations and Economics (SI)

\begin{tabular}{|l|r|r|}
\hline & \multicolumn{1}{|c|}{ BEB } & \multicolumn{1}{|c|}{ Diesel } \\
\hline Number of vehicles & 4 & 8 \\
\hline Period used for fuel and energy op analysis & $6 / 17-5 / 18$ & $6 / 17-5 / 18$ \\
\hline Total number of months in period & 12 & 12 \\
\hline Fuel and energy analysis base fleet kilometers & 82,960 & 304,267 \\
\hline Period used for maintenance op analysis & $6 / 17-5 / 18$ & $6 / 17-5 / 18$ \\
\hline Total number of months in period & 12 & 12 \\
\hline Maintenance analysis base fleet kilometers & 82,960 & 304,267 \\
\hline Average monthly kilometers per vehicle & 1,728 & 3,169 \\
\hline Availability & 76.7 & 85.5 \\
\hline Fleet fuel usage in kWh / liter equivalent & $146,152.3$ & $140,612.9$ \\
\hline Purchased electrical energy in kWh for BEB & $168,274.3$ & - \\
\hline Roadcalls & 11 & 3 \\
\hline Total KMBRC & 7,542 & 101,422 \\
\hline Propulsion roadcalls & 8 & 1 \\
\hline Propulsion KMBRC & 10,370 & 304,267 \\
\hline Rep. fleet fuel consumption (L/100 km) & 17.69 & 46.21 \\
\hline Energy cost per kWh / diesel cost per liter & 0.22 & 0.53 \\
\hline Energy/fuel cost per kilometer (based on purchased energy) & 0.45 & 0.25 \\
\hline Total scheduled repair cost per kilometer & 0.05 & 0.06 \\
\hline Total unscheduled repair cost per kilometer & 0.19 & 0.22 \\
\hline Total maintenance cost per kilometer & 0.24 & 0.28 \\
\hline Total operating cost per kilometer & $\mathbf{0 . 6 9}$ & $\mathbf{0 . 5 2}$ \\
\hline
\end{tabular}

Table 3-5. County Connection-Maintenance Costs (SI)

\begin{tabular}{|l|r|r|}
\hline & \multicolumn{1}{|c|}{ Battery } & \multicolumn{1}{c|}{ Diesel } \\
\hline Fleet mileage & 82,960 & 304,267 \\
\hline Total parts cost $(\$)$ & $3,091.45$ & $28,654.96$ \\
\hline Total labor hours & 340.20 & $1,103.30$ \\
\hline Average labor cost $(@ \$ 50.00$ per hour) $(\$)$ & $17,010.00$ & $55,165.00$ \\
\hline Total maintenance cost $(\$)$ & $20,101.45$ & $83,819.96$ \\
\hline Total maintenance cost per bus $(\$)$ & $5,025.36$ & $20,954.99$ \\
\hline Total maintenance cost per kilometer $\mathbf{( \$ / k m )}$ & $\mathbf{0 . 2 4}$ & $\mathbf{0 . 2 8}$ \\
\hline
\end{tabular}




\section{Appendix. Evaluation Protocol}

In 2012, DOE and FTA established performance and cost targets for FCEBs. ${ }^{3}$ Interim targets were set for 2016 along with ultimate targets that FCEBs would need to meet to compete with current commercial-technology buses. DOE and FTA have not established performance targets specific to BEBs, but the performance targets established for FCEBs were based on typical conventional buses and the targets could be considered appropriate for any advanced technology. Table A-1 shows a selection of these technical targets for FCEBs.

Table A-1. DOE/FTA Performance, Cost, and Durability Targets for FCEBs ${ }^{a}$

\begin{tabular}{|l|c|c|c|}
\hline & Units & 2016 Target & $\begin{array}{c}\text { Ultimate } \\
\text { Target }\end{array}$ \\
\hline Bus lifetime & years/miles & $12 / 500,000$ & $12 / 500,000$ \\
\hline Power plant lifetime ${ }^{b}$ & hours & 18,000 & 25,000 \\
\hline Bus availability & $\%$ & 85 & 90 \\
\hline Fuel fills & per day & $1(<10 \mathrm{~min})$ & $1(<10 \mathrm{~min})$ \\
\hline Bus cost $^{\mathrm{c}}$ & $\$$ & $1,000,000$ & 600,000 \\
\hline $\begin{array}{l}\text { Roadcall frequency (bus/fuel cell } \\
\text { system) }\end{array}$ & $\begin{array}{c}\text { miles between } \\
\text { roadcalls (MBR) }\end{array}$ & $3,500 / 15,000$ & $4,000 / 20,000$ \\
\hline Operation time & $\begin{array}{c}\text { hours per day/ } \\
\text { days per week }\end{array}$ & $20 / 7$ & $20 / 7$ \\
\hline $\begin{array}{l}\text { Scheduled and unscheduled } \\
\text { maintenance cost }\end{array}$ & $\begin{array}{c}\text { \$/mile } \\
\text { Range }\end{array}$ & 0.75 & 0.40 \\
\hline Fuel economy & miles & 300 & 300 \\
\hline
\end{tabular}

a The cost targets for subsystems (power plant and hydrogen storage) are not included.

b The power plant is defined as the fuel cell system and the battery system.

${ }^{c}$ Cost is projected to a production volume of 400 systems per year. This production volume is assumed for analysis purposes only and does not represent an anticipated level of sales.

d Excludes mid-life overhaul of power plant.

NREL uses a standard evaluation protocol for evaluating the advanced technologies deployed under the FTA programs. Data parameters include the following:

- Bus system descriptions

- Operations duty-cycle description

- Bus use and availability

- Energy/fuel consumption and cost

- Maintenance cost

- Roadcalls

- Infrastructure and facility modification descriptions

- Capital costs

- Implementation experience

\footnotetext{
${ }^{3}$ Fuel Cell Technologies Program Record \# 12012, September 12, 2012.
} 
For each selected fleet, NREL collects all fueling/charging, cost, and maintenance data for a period of 12 to 18 months to provide a full year of operation data for the analysis. For each site, NREL collects data on conventional technology baseline buses for comparison. For most fleets, the baseline buses are diesel buses. For fleets that do not operate diesel buses, the baseline buses are usually compressed natural gas $(\mathrm{CNG})$ buses. Other technologies, such as diesel hybrid buses, will be included in the evaluation if they are available. The best comparisons are made between buses of the same make, model, production year, size, and route deployment. In that case, the only difference is the propulsion system. This is not always possible. NREL works with the transit agency to determine which vehicles the agency has in operation and selects the best possible baseline match for each evaluation based on what is available. The following sections outline the analysis approach for each parameter.

\section{A.1 Bus System Descriptions}

This category of data includes general descriptions of the buses and systems. NREL provides a form that the agency fills out for both the ZEBs and baseline vehicles. The form asks for specifications of the vehicle propulsion system and subsystems as well as accessory equipment. This information documents that the baseline vehicles are similar in equipment to the advanced technology buses. NREL collects these data at the beginning of the project; however, changes may be required if major systems are altered.

\section{A.2 Operations Duty-Cycle Description}

NREL collects duty-cycle descriptions from the transit agency to understand how the ZEBs are used compared to the baseline buses. Data collected include descriptions of the expected routes, operating hours during a typical work day, number of days per week that the vehicle is operated, the amount of fuel and range (in miles) that are expected during a given work day and between fueling/charging, and other information on how the vehicles are used. Transit agencies typically provide these data in text format. NREL uses the data to determine an average operating speed. Occasionally, bus OEMs provide detailed Global Positioning System (GPS) data from the onboard data collection systems. In those cases, NREL will develop specific route maps showing the planned use of the ZEBs.

\section{A.3 Bus Use and Availability}

Bus use and availability are indicators of reliability. Lower bus usage may indicate downtime for maintenance or purposeful reduction of planned work for the buses. NREL expresses bus use as average miles accumulated per month. NREL uses a general target of 3,000 miles per month for this metric; however, the monthly miles for each agency will vary depending on the planned use of the buses. If a ZEB fleet does not meet this target, it does not indicate a specific limitation for the technology. NREL collects the mileage data for the ZEBs and baseline buses and calculates average monthly miles accumulated per bus.

Availability is the number of days the buses are actually available compared to the days that the buses are planned for operation, expressed as percent availability. The analysis calculates availability for morning pull-out and doesn't necessarily reflect all-day availability. Transit agencies typically have a target of $85 \%$ availability for their fleets to allow time to handle scheduled and unscheduled maintenance. The sources for availability data vary from fleet to fleet. NREL works with each agency to determine the best source for the data. In addition to 
tracking the overall availability, NREL collects the reasons for unavailability. Categories for unavailability include issues related to general bus systems, preventive maintenance, electric drive, battery system, and fuel cell system. These data help indicate whether the issues are due to the advanced technology components or are problems with conventional bus systems.

\section{A.4 Energy/Fuel Consumption}

Data needed for this category include records of each fueling or charging event. For liquid- and gas-fueled buses, NREL collects individual fueling records (amount of fuel, odometer reading, hour reading, date, and fueling time) and fuel prices (each fuel, each time the fuel price changes - price and date). For the BEBs, NREL collects daily energy use (total kWh, number of charges, miles traveled) and utility bills for each charging location (in depot or on-route fast charger). NREL analyzes these data to calculate monthly fuel economy and fuel/energy cost per mile. For the BEBs, NREL uses the bus energy use and utility energy data to calculate the charging losses.

To compare the electrical energy used by the BEBs to the diesel fuel energy used by the baseline hybrid and diesel buses, the electrical energy is converted to diesel gallon equivalent (dge). The energy content of each fuel ${ }^{4}$ is used to create the conversion factor shown below:

Lower heating value for diesel fuel $=128,488 \mathrm{Btu} / \mathrm{gal}$

U.S. average energy content of electricity $=3,414 \mathrm{Btu} / \mathrm{kWh}$

Conversion factor $=128,488 \mathrm{Btu} / \mathrm{gal} / 3,414 \mathrm{Btu} / \mathrm{kWh}=37.64 \mathrm{kWh} / \mathrm{gal}$

\section{A.5 Maintenance Cost}

Maintenance data include each repair action - such as preventive (scheduled) maintenance, unscheduled maintenance, and roadcalls — and date of repair, labor hours, number of days out of service, odometer reading, parts replaced, parts cost, and descriptions of problem reported and actual repair performed. NREL also collects data and cost for any fluid addition (oil, transmission fluid, deionized water). Engine oil changes are included as part of preventive maintenance. The maintenance data are used to estimate operating costs (along with fuel and engine oil consumption costs). Because accident-related repairs are extremely variable from bus to bus, NREL eliminates those costs from the analysis for both ZEB and baseline bus fleets.

NREL also eliminates warranty cost data from the operating cost calculation because those costs are covered in the purchase price of the buses. Labor costs may be included in this analysis depending on the mechanic who performed the work (operator or manufacturer) and whether those hours were reimbursed under the warranty agreement. For consistency, NREL uses a labor cost of $\$ 50 /$ hour. Cost per mile is calculated as follows:

$$
\text { Cost per mile }=[(\text { labor hours } * \$ 50 / \mathrm{hr})+\text { parts cost }] / \text { mileage }
$$

NREL calculates total cost per mile as well as scheduled and unscheduled cost per mile. To understand the differences between conventional and ZEB technology, NREL presents the cost

\footnotetext{
${ }^{4}$ Alternative Fuels Data Center, fuel properties database, http://www.afdc.energy.gov/fuels/fuel properties.php.
} 
per mile by vehicle system. The work orders are coded using vehicle maintenance reporting standards (VMRS) developed by the American Trucking Association to aid the industry in tracking equipment and maintenance using a common standard. The propulsion-related systems were chosen to include only those systems of the vehicles that could be affected directly by the selection of a fuel or advanced technology. NREL bases the VMRS coding on parts that were replaced. If there was no part replaced in a given repair, then NREL selects the code by the system being worked on. System categories include the following:

- Cab, body, and accessories: Includes body, glass, cab and sheet metal, seats and doors, and accessory repairs such as hubodometers and radios

- Propulsion-related systems (subsystems included):

$\circ$ Engine/power plant (includes fuel cell for FCEBs)

- Electric propulsion system

- Fuel system

○ Exhaust

○ Non-lighting electrical system — general electrical, charging, cranking, ignition

- Air intake

○ Cooling

○ Transmission

○ Hydraulic

- Preventive maintenance inspection (PMI): Labor for inspections during preventive maintenance

- Brakes: Includes brake pads, disks, calipers, anti-lock braking system, and brake chambers

- Frame, steering, and suspension

- HVAC

- Lighting

- Air system (general)

- Axles, wheels, and drive shaft

- Tires.

\section{A.6 Roadcalls}

All roadcalls are marked in the maintenance data collected. A roadcall, or revenue vehicle system failure, is defined as a failure of an in-service bus that causes the bus to be replaced on route or causes a significant delay in schedule. If the problem with the bus can be repaired during a layover and the schedule is kept, this is not considered a roadcall. The analysis described here includes only roadcalls that were caused by "chargeable" failures. Chargeable roadcalls include systems that can physically disable the bus from operating on route, such as interlocks (doors, air system), engine, or things that are deemed to be safety issues if operation of the bus continues. They do not include roadcalls for issues with components such as radios, fareboxes, or destination signs.

The transit industry measures reliability as mean distance between failures, also documented as miles between roadcalls (MBRC). MBRC is calculated by dividing the number of miles traveled by the number of roadcalls. NREL uses the roadcall data to calculate cumulative MBRC over time. MBRC results in the report are categorized as follows: 
- Bus MBRC: Includes all chargeable roadcalls. This category includes propulsion-related issues as well as problems with bus-related systems such as brakes, suspension, steering, windows, doors, and tires.

- Propulsion-related MBRC: Includes roadcalls that are attributed to the propulsion system and is a subset of the bus MBRC. Propulsion-related roadcalls can be caused by issues with the engine, transmission, batteries, fuel cell system, or electric drive.

- Energy storage system (ESS)-related MBRC: Includes roadcalls attributed to the ESS only (specific to BEBs).

- Fuel cell system-related MBRC: Includes roadcalls attributed to the fuel cell and balance of plant only (specific to FCEBs).

Transit agencies are required to report costs and specific performance data to FTA through the National Transit Database (NTD). After Congress required data reporting in 1974, FTA developed the NTD as a repository of financial, operating, and asset condition data for American transit agencies. These data are published on the NTD website. ${ }^{5}$ The vehicle maintenance reliability metrics used by the NTD are as follows:

- Major mechanical system failure: A failure of some mechanical element of the revenue vehicle that prevents the vehicle from completing a scheduled revenue trip or from starting the next scheduled revenue trip because actual movement is limited or because of safety concerns.

- Other mechanical system failure: A failure of some other mechanical element of the revenue vehicle that, because of local agency policy, prevents the revenue vehicle from completing a scheduled revenue trip or from starting the next scheduled revenue trip even though the vehicle is physically able to continue in revenue service. Examples include a malfunction in the farebox or the air conditioner.

Total revenue system failures would be a sum of the two categories. The NTD categories do not exactly match the roadcall definitions used in the standard NREL protocol. The primary difference is that NTD's other mechanical system failures category includes failures of items such as fareboxes and destination signs. This results in the NTD total failures being higher than that of the NREL analysis. Removing these failures from the NTD data would result in higher overall industry average MBRC. In addition, the NTD major mechanical system failure category includes some roadcalls that are not for the propulsion system. The NTD has no category for power plant failures; therefore, there is no direct comparison for fuel cell system-related or ESSrelated MBRC.

\section{A.7 Infrastructure and Facility Modification Descriptions}

At the beginning of the data collection period, NREL collects details on the fleet's operations including a description of facilities and services, maintenance and fueling practices, and any other information needed to get a complete understanding of the fleet's experience with the ZEBs. Descriptions of facilities include fueling, charging, maintenance, and vehicle storage facilities that may be associated with the ZEBs.

\footnotetext{
${ }^{5}$ NTD website: https://www.transit.dot.gov/ntd.
} 


\section{A.8 Capital Costs}

Data on capital costs include costs for any facility modifications that are required for operation of ZEBs. The vehicle capital costs include the costs for new vehicles and propulsion systems.

\section{A.9 Implementation Experience}

The experiences of a transit agency in implementing any new technology are an important part of fully understanding the current status of that technology. NREL collects data on the fleet implementation experience to document the background work needed for successful implementation of ZEBs, as well as some of the potential pitfalls and lessons learned. The types of information collected in support of this activity include:

- Documentation of the history that led to the agency's decision to purchase ZEBs, its previous experience with alternative fuels, etc.

- Roles of important supporting organizations such as vehicle manufacturer and supplier, fuel suppliers, and federal, state, or local government agencies.

- Specific incentives for advanced technology vehicles, and regulations or disincentives for the other options that helped form the agency's decision to purchase ZEBs.

- The driver, fleet personnel, and customer perceptions of the new technology vehicles.

- Special fleet needs such as mechanic, driver, or technician training requirements, special equipment, and safety issues.

- A description of the training implementation strategy including employee orientation, operations and maintenance personnel, and the costs of this training.

- What it took to bring these vehicles into revenue service, and what technical/nontechnical hurdles were overcome. 